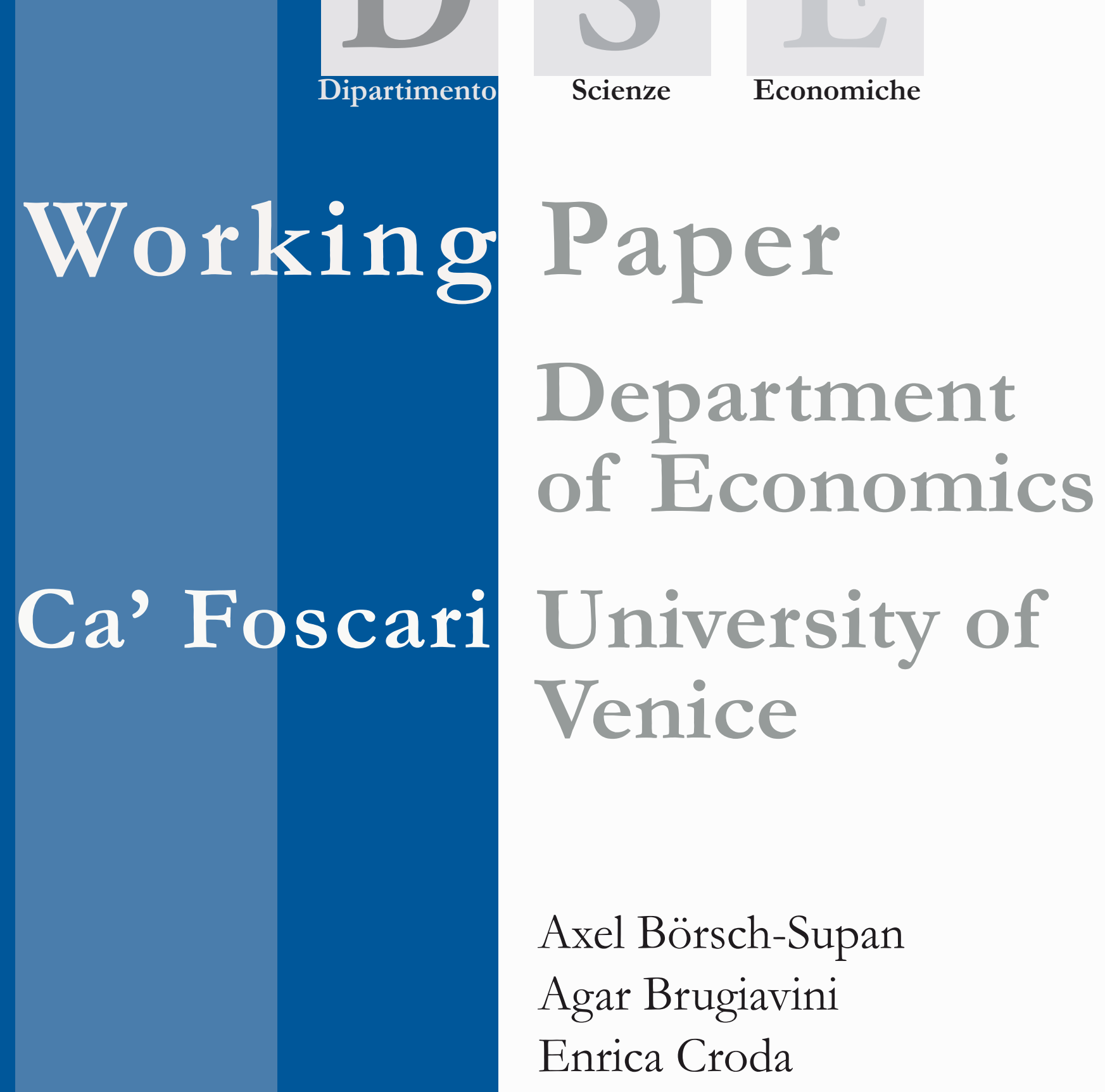

The Role of Institutions in European Patterns of Work and Retirement 


\title{
( ) \\ The Role of Institutions in European Patterns of Work and Retirement
}

\author{
Axel Börsch-Supan \\ MEA Mannheim Research Institute for the Economics of Aging, University of Mannheim

\section{Agar Brugiavini} \\ Department of Economics, Ca' Foscari University of Venice and SSAV \\ Enrica Croda \\ Department of Economics, Ca' Foscari University of Venice and SSAV
}

First Draft: October 2008

\begin{abstract}
This paper uses the Survey of Health, Ageing and Retirement in Europe (SHARE) to investigate the role of pension and social security institutions in shaping the European patterns of work and retirement. We provide evidence on the extent of "unused capacity" in labor force, on pathways to retirement and on the relationship between actual health status and disability take up. We find that institutional differences between countries explain much of the cross-national differences in work and retirement, while differences in health and demographics play only a minor role.
\end{abstract}

\section{Keywords}

Aging, employment, retirement, health, disability, social security institutions, SHARE

\section{JEL Codes}

J14, J18, J26, J68, I12, C81

Address for correspondence:

Enrica Croda

Department of Economics

Ca' Foscari University of Venice Cannaregio 873, Fondamenta S.Giobbe 30121 Venezia - Italy

Phone: (++39) 0412349234

Fax: (++39) 0412349176 enrica.croda@unive.it

This Working Paper is published under the auspices of the Department of Economics of the Ca' Foscari University of Venice. Opinions expressed herein are those of the authors and not those of the Department. The Working Paper series is designed to divulge preliminary or incomplete work, circulated to favour discussion and comments. Citation of this paper should consider its provisional character.

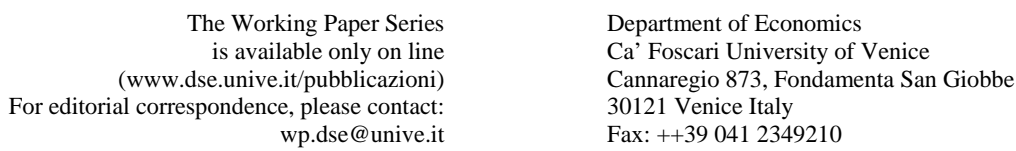




\section{Introduction*}

Welfare provisions for the older population occupy much of the political debate around reforms and sustainability of social security programs in Europe. ${ }^{1}$ On the one hand, a higher life expectancy calls for a later retirement age in order to keep the balance between time spent working and time spent in retirement approximately constant. On the other hand, early retirement, unemployment and disability provisions are widespread benefits of social policy that workers do not want to give up easily. Since the increase in longevity has been accompanied with a decline in age-related morbidity, the costs of this social achievement in terms of lost production work and strain on the pay-as-you-go financed pension systems and old-age related welfare programs has become large. Hence, a widely held view amongst economists is that there is "unused capacity" for active work (see for example Gruber and Wise 1999 and 2004).

This paper sheds light on the complex retirement patterns that have emerged in Europe during the recent decades. Retirement patterns, as we will see, are not only complex in each country, encompassing multi-stage pathways via specific pre-retirement schemes, unemployment and/or disability benefits, early retirement pensions and finally normal old-age pensions. They are also very different among European countries, in spite of very similar trends in mortality and morbidity. One obvious explanation for the complexity and

\footnotetext{
* The SHARE data collection has been primarily funded by the European Commission through the 5th framework programme (project QLK6-CT-2001-00360 in the thematic programme Quality of Life). Additional funding came from the US National Institute on Aging (U01 AG09740-13S2, P01 AG005842, P01 AG08291, P30 AG12815, Y1-AG-4553-01 and OGHA 04-064). Data collection in Austria (through the Austrian Science Fund, FWF), Belgium (through the Belgian Science Policy Office) and Switzerland (through BBW/OFES/UFES) was nationally funded. We are grateful to Susann Rohwedder for kindly providing her programming code for the lifetables. We thank Lorenzo Agnoletto, Lisa Callegaro, Christian Goldammer, Giacomo Masier, Giacomo Pinaffo, Stephanie Stuck, Fabian Terner and Elisabetta Trevisan for excellent research assistance. Axel Börsch-Supan: MEA Mannheim Research Institute for the Economics of Aging, University of Mannheim, axel@boersch-supan.de; Agar Brugiavini: Department of Economics, Ca' Foscari University of Venice and SSAV, brugiavi@unive.it; Enrica Croda: Department of Economics, Ca' Foscari University of Venice and SSAV, enrica.croda@unive.it. Comments welcome.

${ }^{1}$ See, for instance, European Commission (2004).
} 
multitude of retirement patterns are the different institutional arrangements in each country. They affect both the supply of, and the demand for, labor at older ages. On the supply side, social security and pension arrangements create opportunities to retire at various ages. There are old-age pensions, disability pensions, sickness and unemployment benefits, which shape the various pathways to retirement, given the health and social conditions of older workers. Institutional arrangements also influence the demand side: it might be optimal for firms to discharge older workers when their productivity does not increase anymore but labor contracts still impose rising wages. Moreover, in many countries it is much cheaper to dismiss older rather than younger workers when a company is forced to restructure because severance payments to older workers are effectively subsidized by early retirement and disability benefits.

Retirement is often described as a direct transition between a situation of full employment and a situation where the individual is fully inactive. However, many European countries have allowed and sometimes encouraged various forms of partial exits from the labor force, before access to normal retirement. The main tools for doing so have been partial retirement schemes, but in many cases pension benefits are not conditioned on being inactive, so that workers can continue working in another job (or even the same) after drawing pension benefits. Hence, exit from the labor force and entry into the pension system have become distinct events. Exit from the labor force can come earlier, at the same time, or later than the entry into the pension system, creating additional complexities in retirement patterns.

This paper is by no means the first paper on retirement patterns in a European or broader international context, see e.g. the work by Kohli et al. (1991) and work by the team around Gruber and Wise (1999, 2004, 2007). Our paper, however, features two key novelties. First, we use the strictly harmonized data from the Survey of Health, Aging and Retirement in 
Europe (SHARE). ${ }^{2}$ The ex-ante and ex-post harmonization permits a much more precise comparison across countries than possible with earlier data sets. Second, SHARE includes not only socio-economic characteristics, but also health data. Health, although obviously a prima facie important driver of retirement, has rarely been used as a quantifiable factor in internationally comparable retirement analyses.

Section 2 of this paper provides an overview of retirement patterns in Europe. In particular, we classify individuals according to a set of mutually exclusive self-reported labor force states. Independently of this self-report, we also ask whether individuals receive a pension, whether individuals receive labor income, and how many hours individuals actually work. This set of independent questions permits us a detailed analysis of the complex and often multi-staged retirement transitions. We show that the quantitative importance of these different routes varies considerably across countries, with the proportion of workers ranging between 20\% (Italy and Austria) and $40 \%$ (Switzerland and Sweden), while the share of retired individuals ranges between 36\% (the Netherlands and Spain) and 62\% (Austria).

A striking finding is that in some countries the proportion of self-assessed "retired" individuals is smaller than the share of individuals who report that they are still working, hence mitigating somehow the amount of "inactivity" estimated for the SHARE respondents.

Section 3 therefore studies the various pathways of retirement in detail. When looking at the various age-ranges, Austrians and Italians, both men and women, seem to exit the labor force at earlier ages than other Europeans. Furthermore, in most countries, exiting from the labor force does not necessarily lead to receipt of a public pension. In some countries, there is some substitutability between different forms of inactivity. For example, the disability pathway in the Netherlands is a well-known and well-documented aspect of early retirement in this country: the percentage

\footnotetext{
${ }^{2}$ For a description see Börsch-Supan, et al. (2005), and Börsch-Supan and Jürges (2006). See also www.share-project.org.
} 
of disabled people in the $60-64$ age group peaks to reach $15 \%$, and it is clearly a substitute to unemployment or early retirement.

The prima facie evidence discussed so far suggests that pension policies adopted by the different countries are an important determinant of labor force participation decisions at older ages. However, there are other determinants of labor force exits. A primary candidate is the health status of individuals. Section 4 therefore investigates the role of health status by restricting the attention to individuals who are in "good health", i.e. to individuals who self-report absence of health problems and/or feature no limitations out of a battery of 14 activities of daily living.

We observe a strikingly high frequency of individuals who are healthy and/or have no limitations but classify themselves as fully retired. This percentage is particularly high in Austria, France and Italy, and it holds even for individuals younger than age 60. Moreover, we find that the strikingly large international variation in disability insurance enrolment rates cannot be explained by health at all; rather, correcting for health status exacerbates these international differences. Institutional features, such as benefit generosity and the need for a medical exam before becoming eligible for disability benefits explain about $75 \%$ of the international variation. These findings strengthen the "unused capacity" view of many economists.

So far, we have assembled cross-national evidence along several dimensions, such as institutions and health. Section 5 gives a closer look also at the within-country heterogeneity of retirement patterns and the role of all the many competing determinants of retirement. We provide a detailed multivariate econometric analysis where the explanatory power of all determinants can be evaluated jointly. We investigate the role played by social security and pension rules in shaping labor supply decisions and analyze the comparative relevance of institutional and individual determinants of transitions through the different routes leading to effective retirement. For this task we exploit information on the labor market position of individuals as well as their health conditions, social and economic 
environment. When explaining retirement decisions we also use a measure of generosity of the pension system ("social security wealth"), defined as the discounted sum of expected pension benefits both from social security and from private pension schemes, and other determinants which can capture preferences about the planning horizon (such as subjective survival probability). Such detailed analysis is possible since the SHARE data contain all these dimensions of the individuals' decision framework.

We find that even after controlling for country indicators (which capture the basic institutional variability across countries) all the above determinants play a role. Good health conditions have a negative effect on retirement; the higher the present value of expected social security benefits relative to household resources, the higher the probability of being retired; and the higher the subjective survival probability the higher the probability of working.

When assembling all these pieces of the puzzle, a clear picture emerges. First, institutions play a very large role in shaping retirement patterns. They explain most of the international variation. Second, within each country, i.e. given the national institutions, health and subjective survival probability explain a substantial share of the remaining within-country heterogeneity of retirement patterns. Third, there is no doubt that there is considerable "unused capacity" in some countries in which they can tap into if they wish to alleviate the strain on their social security systems.

\section{Economic activities of older Europeans: an overview}

The analysis in this paper uses three different concepts of economic activity which are important to distinguish. The first concept is self-reported activity status. The SHARE questionnaire has each respondent classify herself into one of six mutually exclusive labor force states: "worker", "retired", "unemployed", "disabled", "homemaker", or "other". 3 Note that we force respondents to decide whether they feel themselves e.g. as "retired" rather than "working"; there is no option of an in between.

\footnotetext{
${ }^{3}$ This self-reported activity status is coded as variable EP005 in the SHARE data.
} 
The second concept is based on the receipt of income. We ask all respondents whether they receive labor income ("working"), either from employment or self-employment; public transfer payments, including public pensions ("retired"), disability benefits (“disabled"), and/or unemployment compensation ("unemployed"). ${ }^{4}$ We also ask respondents whether they receive private pensions, including private early retirement and disability pensions. $^{5}$

Finally, the third concept is based on actual working hours. The SHARE questionnaire asks every respondent how many hours she actually works. ${ }^{6}$ We use this information to distinguish the states "not working" and "any work at all". In the latter category, we additionally specify the "works more than 15 hours" category.

The three concepts are independent from each other. Of course, many respondents will fall in the two conventional categories: (a) self-reported working, full time working hours, receipt of labor income and no transfer income, or (b) self-reported retired, zero working hours, receipt of a public pension and no labor income. But many other combinations are possible, e.g. (c) a respondent may receive disability benefits (concept 2 ), feels retired (concept 1), but is working some hours anyway from time to time (concept 3 ), or (d) a recipient of unemployment benefits (concept 2) who has been unable to find work for some time (concept 3) and therefore feels retired (concept 1). This set of three independent concepts therefore permits a detailed analysis of the complex and often multi-staged retirement transitions in Europe.

Figure 1 gives a broad impression of the first concept: self-reported activity status. The data refer to all respondents of the first wave collected between September 2004 and June 2005, encompassing both "age-eligibles" (persons born in or before 1954) and their spouses (any age). We focus on workers

\footnotetext{
${ }^{4}$ This information is contained in the SHARE variables EP041, EP045 and EP071.

${ }^{5}$ This information is provided by different categories of EP071.

${ }^{6}$ The answers are coded in variable EP013 in the SHARE data.
} 
and retired individuals and group all other categories in the residual ("allother"). Two observations catch the eye: First, it is immediately apparent that work and retirement are the two prevalent activity states reported in the SHARE sample. Second, already at age 61 more SHARE respondents classify themselves as retired rather than working.

Table 1 provides the details behind Figure 1. It lists the distribution of all six self-reported activity categories with their standard errors, separately by country. The entries are weighted to represent the population aged 50 and older using weights provided with the SHARE data set. ${ }^{7}$

Table 1 shows very large differences in the distribution of self-reported activities across countries, with the proportion of workers ranging between $20 \%$ (Italy and Austria) and $41 \%$ (Switzerland), while the shares of individuals reporting to be "retired" range between 36\% (the Netherlands and Spain) and 62\% (Austria). Striking is also the large difference in the proportion of respondents classifying themselves as "disabled" which is $1 \%$ in Italy but more than $8 \%$ in the Netherlands. In Denmark, Germany and Belgium there are particularly many respondents who classify themselves as "unemployed". This fraction is much lower in Italy and Greece, but also in the Netherlands. Finally, there is a surprisingly large variation in the share of respondents calling themselves "homemaker". It is particularly small in Sweden (just 1\%), very large in Spain (over 32\%) and the other Mediterranean countries, but also the Netherlands (around 21\%)

These stark differences may have several, not mutually excluding explanations. The explanation which interests us most in this paper is that pension policies, in particular early retirement regulations, adopted by the different countries are an important determinant of labor force participation decisions at older ages. Table 1 yields evidence to this hypothesis insofar as countries which feature large shares of one early exit route (say, unemployment) have low shares of alternative routes to labor force exit

\footnotetext{
${ }^{7}$ Individual weights are contained in the variable WGTACI. See Klevmarken, et al. (2006) for details regarding weighting in SHARE.
} 
(say, disability). The gender-age stratification in Figure 2 provides some additional evidence: less than one out of ten men over 65 report themselves as working in all countries (except for Switzerland). Austrians and Italians, both men and women, seem to exit the labor force at earlier ages than other Europeans. In particular, only $10 \%$ of Austrian men between age 60 and age 64 define themselves as working, compared to almost $60 \%$ of Swedish men. This is perfectly in line with the applicable statutory retirement ages in the two countries. We will provide a more detailed analysis in section 3 .

A second explanation are national customs which may drive the type of selfreports visible in Table 1. Evidence for this may be the strikingly large cross-national variance in the share of "homemakers". Figure 2 therefore also adds the gender dimension. The prevalence of self-reported "working" is generally lower for women than for men, mostly because of the relatively large fraction of women who report their status as "homemaker". 8 It is highly probable that "homemaker" women never had a labor market experience during their lifetime. Section 3 will exploit the other two economic activity concepts to better understand potential differences between self-reports and hard answers.

Finally, there are many other personal characteristics which are likely to drive retirement behavior. Section 4 focuses on health as a determinant of age and pathway of retirement, and section 5 will provide a full description, in which all quantifiable characteristics available in the SHARE data are simultaneously included.

\section{Partial retirement, unemployment, disability, and other forms of pre- retirement}

Self-reported activity status could be affected by individual perceptions and also by institutional features of the pensions systems. For example in some countries individuals may be allowed to work while collecting pension benefits (possibly subject to an earnings test) and report themselves retired even if working. One could define this situation "partial retirement" and it is

\footnotetext{
${ }^{8}$ A detailed table by gender and age of all activities is available upon request.
} 
most likely to occur (where allowed) in the years just preceding full retirement. Tables A1 to A4 in the Appendix report the main institutional features of the welfare system which are relevant for the elderly in the SHARE countries: it clearly shows the variability of arrangements and eligibility conditions that different European citizens face.

To investigate further the impact of these different arrangements on actual choices of workers we exploit the different concepts of "working" but also the different concepts of being "retired" or being "disabled".

Table 2 shows how self-reported activity status is not uniquely associated to a single source of income. Not surprisingly, $90 \%$ of Europeans who selfreport as retired receive at least one public or private old-age or early retirement pension. But some of them also receive disability benefits or labor income. Most respondents who self-report as disabled, receive disability benefits (67\%). However, one out of ten of those who self-report as disabled receives labor income, and a similar fraction receives at least one public or private old-age or early retirement pension. One every two respondents who self-report as unemployed receive unemployment benefits, but one out of five receives labor income from employment or selfemployment.

Figure 3 compares the three different notions of working. It reports the prevalence of the self-reported definition of worker with the definition based on receiving labor income and with the definition of "actual worker" i.e. having worked even if for a few hours. For all countries receiving labor income or doing some hours of work is more prevalent than the corresponding self-reported case. This result suggests that although many people do not regard themselves as workers they have some "bridge jobs" in old age.

The different panels of Figure 4 show the prevalence of retirement according to the first (self-reported activity status) and to the second concept (receiving pension income). In Figure $4 \mathrm{a}$, we observe an apparently counterintuitive fact that in all countries (apart from the Netherlands) the 
fraction of recipients is lower than the fraction of self-reported retired. However this is because we limit the definition of pension receipt to old age or early retirement provisions. ${ }^{9}$ Once we allow for survivor's benefits or even for disability benefits the results are reversed (Figures $4 \mathrm{~b}$ and $4 \mathrm{c}$ ). This evidence simply suggests that the retirement condition is perceived as a more general condition than just "being retired from work": it stresses once more the impact that institutions have on economic behavior.

Figures 5 and 6 perform a similar exercise looking at the unemployment condition and the disability condition. The results are striking as there are wide cross countries differences between the two concepts: Belgium and the Netherlands stick out. In the former there are many more people collecting unemployment benefits than self-reported unemployed (presumably these people define themselves retired) while in the latter there are more people collecting disability benefits than self-reported disabled.

To complete the analysis of the working status of older Europeans, in Figure 7 we make use of actual current work status (concept 3) and distinguish workers on the basis of hours worked. We look at both people working "any amount of time" and reporting working 15 hours or more per week. In all countries, both for women and men, there are more elderly people in paid work (actual worker) than self-reported "working”, even when we restrict the condition to people with 15 hours or more of work. This is an important finding which stresses the need to carefully distinguish between selfreported activity status and actual employment. Many social surveys use self-reported activity status to route respondents into either questions on retirement or questions on work; this will miss much of the actual activities done by older people.

Table 3 strengthens this evidence by focusing on the boundary between people who report themselves as "working" (either employed or selfemployed) and those self-reporting "retired". We introduce the category of

\footnotetext{
${ }^{9}$ We take into account both public and private old age pensions and early retirement pensions. War pensions, are also included where they apply.
} 
people who are "retired but working". These are respondents who report themselves as "retired" according to concept 1 but who have done some paid work during the last month as classified by concept 3 , as defined in Section 2. The share of people that can be considered as "retired but working" fluctuates between approximately $1 \%$ in Italy and $9 \%$ in Switzerland. If we use a stricter version of the third concept and define "working" as working for at least 15 hours a week, the share basically stays the same in Italy, but it declines in Switzerland to about 5\%. Looking at the various age classes it emerges that the Scandinavian countries, Germany and Austria are characterized by a flexible transition between work and retirement.

If we take a closer look at the four age categories reported in Table 3, then we see that the flexible transition extends far into the older ages. Denmark sticks out as a country with a particularly high prevalence of "retired but working" respondents. Also Austria and Italy have a large share in the older age ranges.

One may think that such flexible transition into retirement is dominated by part-time occupations. This is not the case. Table 4 shows that among those who work a positive number of hours, there is surprisingly little part time work. Perhaps not surprisingly, before age 65, the proportion of economically active respondents working part-time is much higher for women than for men.

While partial retirement seems relatively frequent in Switzerland as a whole, this is not the case in the youngest age groups: in these age groups, full activity remains the rule. In Greece, partial retirement is already significantly developed between 50 and 54 for men. These findings suggest that in some countries partial or gradual retirement could become an important feature of the labor market.

So far we have combined the first concept of retirement (self-reported activity status) with the second concept (labor income) and the third concept (working hours). However, even for people who are totally inactive and 
define themselves "retired", this does not necessarily correspond to retirement in the sense of the second concept (receiving an old-age pension). In the different countries, an important role is played by non standard - but sometimes dominant - forms of transitions between employment and full retirement. These pathways are generally classified in three main categories defined by the type of transfer income received:

- One pathway is unemployment: people are laid-off from their last job before being eligible to normal pension benefits. They are therefore forced to spend some time in unemployment before being considered or considering themselves as retired.

- A second pathway is sickness or disability insurance. This route should only apply to people for whom early exits from the labor force result from objective health problems. But some countries have also tended to use these benefits as a device for managing general cases of "uneasiness" about work or even obsolescence of a worker, due for instance to the fact that the skills of an old worker are no more recognized or demanded by employers.

- Finally, some countries have created pre-retirement schemes. Sometimes these are sector-specific (for managing large scale redundancies in some declining industries), sometimes these are nation-wide programs.

Figure 8 shows the enormous variability in the prevalence of disability and unemployment at older ages, as defined by the self-reported activity status (concept 1). ${ }^{10}$ Among the Northern countries, the Danish and the Dutch cases provide a clear illustration of the substitutability between pathways. While in Denmark the prevalence of unemployment is far higher than in the other countries (particularly at ages 55-60), the importance of the disability route for the Netherlands is a well-known and well-documented aspect of the management of older workers in this country: the percentage of disabled

\footnotetext{
${ }^{10}$ The age profiles in Figure 8 are smoothed to remove the sampling variability that is observed in the raw data.
} 
people in the 60-64 age group peaks to reach almost 20\%. The Dutch unemployment rate in this group is quite low, one of the lowest in the entire sample of countries, and we observe that the share of disabled people drops to about $2 \%$ around age 65 , which is the age at which the majority of Dutch people, including the disabled, move to the "retired" category.

Among the mid-European countries, Germany is a country where unemployment is highly relevant as a pathway to retirement, while disability is very low - in a striking contrast to the neighboring Netherlands. France has a peak in self-reported disability status at early ages (around 56) while Switzerland has a late peak (at about age 63).

In the ages which typically precede retirement, a variety of patterns emerges for the southern countries. Disability is almost non existent for Italy and Greece before age 60 . It remains so also after age 60 in Italy. This may be due to the prevalence of early retirement at a very young age: Italy displays low or very low rates for both unemployment and disability. In Greece, disability increases rather than decreasing at the age where people move into retirement: a puzzle to be further investigated. Spain is atypical: the profile of unemployment is relatively flat.

As much as the self-reported activity status did not necessarily correspond to the receipt of labor income or hours worked, the self-reported activity status shown in Figure 8 does not fully correspond to the receipt of the transfer income associated with that status. This holds especially for the Nordic countries where self-reported disability status is less frequent than the receipt of a disability pension (this was called concept 2 in section 2). Figure 9 therefore shows the prevalence of disability insurance benefits among respondents between ages 50 and $65 .{ }^{11}$ Again, the cross-national differences are striking. We can distinguish four country groups. Very high enrolment rates exist in Denmark, the Netherlands and Sweden. Between 13 and 16 percent of individuals aged between 50 and 65 receive disability

\footnotetext{
${ }^{11}$ For a precise definition of disability insurance in each SHARE country, see Table A3 in the Appendix.
} 
insurance benefits in this first group of countries. The second group has enrolment rates around the average enrolment rate of $7.5 \%$. This group consists of Switzerland and Spain. Here the enrolment ranges from 6 to almost 10 percent. Belgium, Germany, France and Italy, the third group, have below average enrolment rates between 4 and 6 percent. In Austria and Greece less than 3 percent of individuals aged between 50 and 65 receive disability insurance benefits.

The evidence presented so far exhibit a puzzling feature of the European welfare state. First, the differences among the three concepts of retirement are remarkable. There are cleavages between self-reported activity status and actual activities, and, even more impressive, there are large cleavages between status and public transfer receipt. Second, the cross-national differences among the variants of "the" European welfare state are striking. They are very unlikely generated by differences in the underlying socioeconomic and health characteristics of the respondents; rather, these different patterns suggest institutional differences and their power to shape retirement decisions: $:^{12}$ depending on national arrangements, access to the various pathways may be relatively straightforward, and financially more or less attractive also resulting from the labor market configuration and in particular from labor demand.

Eventually, these pathways lead to retirement. Figure 10 shows the transitions, defined of self-reported activity status (concept 1$){ }^{13}$ The age pattern of retirement shows an interesting regularity. For most countries, retirement is about $100 \%$ at older ages, say, after age 70 . However, this does not hold for the Mediterranean countries, Belgium and the Netherlands. Theses are the countries with the highest number of respondents who report themselves as homemakers (see Table 1). This phenomenon results from the

\footnotetext{
${ }^{12}$ More detailed descriptions of the institutional arrangements that could affect these patterns can be found in Blöndal and Scarpetta (1998) or Gruber and Wise (2004).

${ }^{13}$ The age profiles in Figure 10 are smoothed to remove the sampling variability that is observed in the raw data.
} 
low levels of women's labor force participation in these countries for the relevant cohorts.

The northern countries show a much steeper retirement increase than the southern countries. For Mid-European and Southern countries, the ages at transition to retirement differ significantly across countries: the age at which $50 \%$ of the people report themselves as retired is 58 for Austria and 65 for Switzerland, 60 for Italy and 65 for Spain. Again, due to the high prevalence of "homemaker" status, these ages cannot be exactly interpreted as median ages at retirement. For instance, in Spain, the number of people reporting themselves as retired stays at $60 \%$ between ages 70 and 80 . As a consequence, the "median" age at retirement should be better defined as the age at which one half of these $60 \%$ are retired, which takes us closer to 63 . Nevertheless, it remains that transition into retirement occurs later in Spain than in Greece, and later in Greece than in Italy.

Table 5 turns to the second concept of retirement, namely to the type of income that respondents receive, and provides another way to understand the total effect of welfare arrangements and labor market configurations on exits from the labor market. This table reports the average age of first benefit collection among all respondents who currently receive an old age pension (including early retirement pensions) or disability benefits (public and private sources). Once again, the table shows the remarkable variability in the average effective retirement age across countries (for men the lowest is Austria at 58.8 and the highest is Denmark at 65).

\section{Retirement age and reasons for retirement: Is there unused capacity?}

A widely held view amongst economists is that there is "unused capacity" for active work. ${ }^{14}$ While the analysis in the previous sections yields strong evidence that institutional factors play a dominant role in shaping retirement transitions, this section takes a closer look at health before rushing to premature conclusions. Only if bad physical or mental health can be ruled

\footnotetext{
${ }^{14}$ The idea of "unused capacity" has been first elaborated by Gruber and Wise (1999) who argue that there is an implicit tax on labor labor providing the incentive to retire early.
} 
out as an explanation for high inactivity rates at relatively young ages can we speak of "unused capacity".

Direct evidence of the reasons for retirement, disaggregated by gender and age class, is provided in Table 6, which shows the distribution of "reasons for retirement" for the self-reported retirees. The original SHARE question provides 9 answer categories that are not mutually exclusive. ${ }^{15}$ We have regrouped these answers into five major headings:

(1) "normal" transition due to the fact that people had become eligible either for a public or private pension;

(2) early retirement including undesired early retirement, such as in the case of people to whom a early retirement option or a pre-retirement has been proposed or imposed (e.g. because of a redundancy);

(3) retirement due to personal health reasons;

(4) retirement in order to "enjoy life" or retire at the same time as the spouse does;

(5) all other reasons, including various family or personal reasons.

The first one of these five motives dominates in the older age classes. Striking, however, is the large international variation, particularly in the youngest age class. For instance, early retirement is chosen by $66 \%$ of Swiss males in the 55-59 age range and 50\% males in the Netherlands. In Sweden and Greece it is less than $11 \%$. At age $65+$, eligibility for a pension is chosen as a reason for retirement among $86 \%$ of Greek and $83 \%$ of Spanish males, but only by $32 \%$ of Dutch males. Health, in turn, is reported by $22 \%$ of Danish males, $21 \%$ of German males and only $8 \%$ of Greek males aged $65+$ as a reason to retire. This very large cross-national variation is the role of health as a self-reported driver of retirement also extends to women.

It is notable that the international pattern of health as retirement motive does not fit obvious explanations. For instance, it seems natural to find that health reasons are less frequently reported in a country like Italy where age at

15 The reasons for retirement are asked in question EP064 of the SHARE questionnaire. 
retirement is low: since health declines with age, health constraints should weigh less in countries where retirement is offered at lower ages.

The role of health as a main driver of retirement is further put into doubt by Figure 11, which shows the distribution of actual work and retirement by restricting the attention to individuals in "good health". Being in "good health" is defined on the basis of two indicators: (i) self-reported absence of health conditions that limit the ability to work ("healthy"), and (ii) absence of any limitation in doing fourteen activities or instrumental activities of daily living (ADL and IADL, "functioning"). In order to make the comparison sharper we focus on three groups of individuals: those who selfreport as working and are actually currently active; those who self-report as retired and have no hours of work (retired); and those who self-report as retired but do some hours of work (retired but work). A strikingly high frequency of respondents in Austria, France, Italy and Belgium have no limitations or are "functioning" on the one hand, but, on the other hand, report themselves fully retired. This is true even for people in early retirement (i.e., younger than 60).

Figure 12 turns to what might be considered the clearest case in which health should play a major role: receipt of disability insurance benefits (the second concept in section 2). Indeed, self-reported health is much worse among those who are on disability insurance; see the left panels of Figure 12. 19.7 percent report poor health among the enrolled, only 2.9 among the not enrolled. In turn, only 9.8 percent report excellent or very good health among the enrolled, while this share is 42.5 percent among the not enrolled. Nonetheless, it is a striking finding that almost 10 percent report excellent or very good health in spite of being on disability insurance.

The health differences, however, are much less pronounced when measured more objectively as grip strength. Respondents use a dynamometer which they have to press 2 times with each hand; the maximum grip strength measured is reported in the right panels of Figure 8. Average grip strength is 38.1 kilograms among the not enrolled, while individuals on disability 
insurance have lower grip strength of 34.4 kilograms. Grip strength has a fairly large standard deviation (about 13 kilograms) but the difference is statistically significant in this large sample.

The discrepancy between very large self-reported health differences and significant but less pronounced differences in the more objective grip strength measure may hint at justification bias of self-reported health (Sen, 2002). Individuals who have enrolled in disability insurance may justify this by reporting a lower health status than what can be measured more objectively by grip strength.

These findings are even more disturbing when carried to the country level. The left panel of Figure 13 correlates the percentage of respondents aged 50-64 who are enrolled in disability insurance with the percentage of same aged respondents who self-report very good or excellent health. The correlation is actually positive: Denmark with a high percentage of respondents reporting good health has also the highest share of respondents in disability insurance. This perverse correlation vanishes once objective health measures are used (such as grip strength and other indicators), see the right panel of Figure 13. One would, however, expect a strong negative correlation if health were the main driver of receiving disability benefits.

While health may not be the main concern, respondents quite definitely feel relieved when they retire. Evidence is provided by Table 7. It presents answers to the question whether retired people have viewed their retirement as a positive or a negative event. Retirement is described as a relief by a large majority of respondents. Only between $2 \%$ and $13 \%$ of retired respondents see it as an essentially negative experience ("a concern"). This is concentrated in the "Club Med" countries: more than 13\% of Greek retirees, and more than $10 \%$ of Spanish and Italian retirees see retirement as a concern.

In conclusion, then, this section suggests the presence of a well-known social policy dilemma. In many countries, pathways to early retirement, such as pre-retirement schemes, unemployment compensation or disability 
insurance, are frequently taken. This frequency does not correlate well with health. This gives the notion that some countries introduced early-retirement institutions that create "unused capacity" much weight. The fiscal and economic costs associated with these early-retirement institutions are large and pressing. Most early retirees, however, express gratitude for the early relief through retirement, an indicator for the large political costs of reforming the early-retirement institutions.

\section{Econometric Evidence}

The descriptive evidence of the preceding sections, while suggestive of important correlations between early retirement and institutional driving forces, does not allow for causal inference. In this section, therefore, we carry out multidimensional analyses accounting for various determinants simultaneously. We focus on the self-reported activity status (concept 1), in particular on the decision to work or retire, in the first subsection, while we take a closer look at disability insurance enrolment (concept 2 ) in subsection 2. Our main interest is to measure the influence of institutions, and compare this with the influence of other potential determinants such as age, gender, health, and education. The effect of institutions and labor market configuration is captured in several ways. In the analysis of the retirement decision, we use country-dummies and a measure of the generosity of the social security systems. In the analysis of disability enrolment, we make use of a full set of country-specific indicators which characterize the generosity of the disability insurance systems.

\subsection{The retirement decision}

In the analysis of the retirement decision, we rely on country dummies to pick up all dimensions of country-specific effects that are not captured by country-specific differences in all other variables (e.g., health and education). The generosity of the social security system is measured through the so called "social security and pension wealth" (SSW), defined as the present discounted value of expected future benefits from social security and pensions, discounted at current age by both a given interest rate and the 
conditional survival probability. In this definition we include both public social security benefits for old age and/or early retirement and private pensions. ${ }^{16}$ For retirees and inactive people we assume that - in real terms future expected benefits are equal to current benefits. For workers, we exploit a question on expected replacement rates at the expected retirement age. Hence we project earnings to that age and calculate the first expected benefit (pension) and the SSW in turn. In the absence of longitudinal data, we cannot measure dynamic incentives of the welfare system, hence this variable captures the differential generosity of the system in the different countries and for the different groups of workers. The advantage is that it is a money-stock measure which is comparable across all individuals of the sample. We use the SSW variable in relative terms, i.e., divide it by total household income (SSWREL). This is done to control for the fact that SSW would pick up the general "economic welfare" of the individual rather than the generosity of the pension system to this individual. Total household income is a good indicator of resources available to an individual and at the same time it does not strictly correlate with her earnings or social security benefits.

The second important explanatory variable is health. Health conditions are captured by two indicator variables. They are defined exactly as in the preceding section: first, as the self-reported absence of problems hindering work, and second as the absence of any among 14 ADL and IADL limitations. $^{17}$

Other potential determinants of retirement are age, education, gender, but also preferences. We introduce a variable that captures a feature of preference which has been proved relevant in studies of retirement-saving,

\footnotetext{
${ }^{16}$ Details on variables construction are provided in a separate Appendix, available upon request. The subjective survival probability is described in Borsch-Supan et al. (2005). It is essentially the selfreported chance of reaching a target age- this is at least 10 years ahead for younger people and it is closer for the very old.

${ }^{17}$ Since this paper rests on a single cross-section, we do not attempt to explain the causality between health conditions and economic outcomes, i.e. we take current health conditions as given. They may affect future economic outcomes, but only with a lag.
} 
particularly in the US. ${ }^{18}$ This is the "expected life horizon", which is related to the planning horizon of the individual. Some authors also interpret this variable as the rate of impatience. In our sample we proxy this variable and we rely on specifications making use either of the subjective probability of surviving to a target age or of the product of this probability with the length of the proposed target lifespan. ${ }^{19}$ The former is a simple measure of the perceived chance to reach a target age, the latter applies this measure to the actual difference between the target age and the current age.

We relate the probability of being retired to these potential determinants by a simple reduced form equation, for which we can provide a latent utility interpretation: we assume that the individuals in our sample have compared the utility value of working to the utility value of retiring and have chosen the activity which generates the highest utility value. Table 8 shows estimation results when the outcome variable takes the value 1 for a person self-reporting "retired" according to concept 1 , and 0 for self-reporting "working". Estimation rests on 13,244 SHARE respondents who are working or retired. We exclude "homemaker", disabled, unemployed and "other activities" cases, and restrict the sample to individuals between age 50 and age 69 because very few respondents are active after age 70. Results, based on a probit specification, are shown both in the absence of countrydummies (first two columns) and including these dummies. The first (and the third) column of Table 8 uses the subjective survival probability while the second (and the fourth) column include the expected lifespan in the specification.

Health makes a difference. Individuals who are "functioning" are - other things being equal - less likely to be retired while the presence of limitations in daily activities increases the probability of being retired. The other socio-economic characteristics also affect retirement as one might

\footnotetext{
${ }^{18}$ For the studies on saving see for example Gustman and Steinmeier (2000) and Munnell et al (1999). The informational content of subjective survival probability has been appraised, among others, by Hurd and McGarry (1997).

${ }^{19}$ It should be noted that for SSW we make use of life tables for the different countries and not of the subjective probability of survival.
} 
expect. Of special interest may be our preference measures: both the subjective survival probability and the expected lifespan have a negative effect on such a probability (i.e. the longer the planning horizon the more the chance of being a worker).

The main result, however, is that, even controlling for all these characteristics, the variable SSWREL, which captures the generosity of the social security and pension system, is significantly and positively associated to the retirement probability - i.e. institutions play a significant role. Differences in health and other socio-economic characteristics do not explain the cross-national variation in activity rates between age 50 and 69 .

One might argue that our generosity variable captures other country differences which have nothing to do with benefit generosity. This is not the case, see columns 3 and 4, in which we add a set of country-dummies. The essential results are unaffected and almost all countries dummies show a significant marginal effect, with respect to Germany, chosen as the reference country. Compared to Germans, Belgians and also Italians, Greeks and Austrians are more likely to be retired.

We conclude that, over and above general institutional or other differences specific to a country, the generosity of the pension system itself matters a great deal in making individuals retire or keep on working.

\subsection{Enrolment in disability insurance}

The preceding section was based on the concept of "perceived" or selfreported retirement. In this subsection, we investigate the second concept of retirement, namely receipt of a benefit income. As stressed earlier, there are many institutions providing benefit income for retirees, and they differ across countries, such as public and private old-age pension systems, unemployment insurance, disability, incapacity and sickness insurance. This subsection focuses on disability insurance. Disability insurance is of particular interest in this paper. Figures 12 and 13 displayed a surprisingly 
small cross-national correlation between health and disability insurance enrolment. One interpretation of these findings is that country-specific rules and regulations exert a stronger influence on disability insurance uptake than the health status of the enrolled individuals. This would constitute a remarkable tension between the original aim of disability insurance to cover health-related disabilities, and actual health.

We therefore measure health more extensively than in the previous exercises and include a broad set of health measures, ranging from selfreported health to more objective measurements of the functional physical (as above, ADL: activities of daily living, IADL: instrumental activities of daily living) and mental health status (CES-D test battery of mental health). ${ }^{20}$

To indicate the power of institutions, we make use of previous work by the OECD and include a set of variables which characterize the generosity of the disability insurance system in each country. These variables measure coverage, minimum disability level required for full benefits, benefit generosity, medical assessment, vocational assessment, and the generosity of unemployment benefits. ${ }^{21}$

In addition, we include similar socio-demographic characteristics (such as age, gender, and education) as in the previous estimations.

We run three regressions: a probit model of being enrolled in disability insurance; a Weibull proportional hazards model of the age when an individual enrols in disability insurance, and finally a simple linear model for the probability to be enrolled into disability insurance. Table 9 presents the results in four blocks: demographic variables, health variables, institutional variables, and interactions among them.

A first finding is the similarity among the three specifications. A second observation is the large unexplained variation. The (Pseudo-) $\mathrm{R}^{2}$ in the two

\footnotetext{
${ }^{20}$ SHARE collects EURO-D as depression measure in the main survey and CES-D in the drop off. We have used CES-D where available and imputed CES-D from EURO-D where necessary.

${ }^{21}$ These variables are taken from Annex A.2.1 in OECD (2003).
} 
probability models is slightly higher than 0.25 ; a quarter of the individual variation in our micro data is not explained in spite of a rich specification of health. The duration model has a somewhat lower explanatory power. This is in line with the findings of OECD (2003) where only little correlation between "medical disability status" and "disability enrolment status" was found.

Demographic variables are jointly significant. Women have a lower probability to enrol into disability insurance, conditional on health. Also this was a finding of OECD (2003). Older age increases to probability to be enrolled until about age 63 . We apply a piecewise linear specification, with breakpoints at ages 55 and 60 . Notable is the sharp increase in the enrolment probability between ages 50 and 55 .

All health variables are strongly significant. Noteworthy is the significant effect of mental illness, measured by the CES-D battery, conditional on physical health, and the strong effect of instrumental activities of daily living (IADLs) probably picking up work-related disability. Given these functional measures, self-reported health remains highly significant and quantitatively large.

Demographics and health explain, in isolation, about a sixth of the total variation of the linear model. This is not much, and corresponds to the impression already gained in previous sections and estimates.

The institutional variables are highly jointly significant. Since they are country-specific and thus have much less variation than the micro data, we use the "cluster" specification to correct the t-statistics accordingly. All measures are scored by the OECD from 0 to 5 . Coverage measures on a 0 to 5 scale which population groups are eligible for insurance. The highest score is given if disability insurance covers the entire population; the lowest score if only employees are covered. A broad coverage increases disability enrolment, but the effect is surprisingly small and insignificant. A lenient minimum disability level to claim benefits has more influence on disability insurance uptake and is significant in all three specifications. The generosity 
of benefits is significant, but with an unexpected negative sign, as is the disability level required for full benefits. The strictness of a medical exam reduces disability uptake. Whether vocational considerations play a role in the eligibility process or not is insignificant, as is the permanence of benefits.

The last institutional variable measures the duration and benefit level of unemployment compensation, a possible alternative to disability insurance as an early retirement device. It is scored 5 for a short duration and lower unemployment benefits than disability insurance benefits. Indeed, tight unemployment insurance increases disability insurance enrolment in a highly significant and quantitatively important way.

Finally, we also interact the institutional variables with selected demographic and health variables. These interactions explain 20.6 percent of the total variation in the linear model, thus more than demographics and health together. They exhibit some interesting features, especially when compared to the institutional variables alone. They explain some of the surprising finding discussed above. For example, the surprisingly small influence of coverage turns into a very large effect for women and those of poor health. The latter is straightforward to explain; the former maybe a result of the low labor force participation of European women who have difficulties to be eligible for a normal old-age pension and thus may seek disability pensions. This corresponds to the very high female enrolment in some countries; in Germany, a lenient eligibility to disability insurance for women was explicitly a policy instrument in the early 1980 s.

Another example for the importance of interaction effects is the generosity variable, which carries an unexpected negative sign in the overall regression, but is strongly positive for the older part of the sample (age 60 and over).

The regression results of Table 9 are somewhat abstract. They receive some life in the following exercise: we predict in a counterfactual simulation exercise which share of our sample individuals would take up disability 
insurance if all countries had the same demographic composition, the same distribution of health, and/or the same institutional characteristics as the average of the SHARE countries. By counterfactually wiping out one kind of difference among countries, we can graphically display the influence of the variable having created those differences in the first place. Take the example of health. If health were the main driver of disability insurance enrolment, making health counterfactually equal across all countries should also make disability insurance enrolment rates close to equal in all countries.

The results of this exercise are striking, see Figure 14. The counterfactual simulation holding eligibility and benefit generosity indicators constant produces much more similar disability uptake rates than holding demographics and health constant. The only outlier is Switzerland, where uptake rates would be extremely low under average generosity.

A simple "back-of-the-envelope" regression confirms the above results. Regressing the aggregate enrolment rates in the small sample of 13 countries on five of the above indicator variables (coverage, minimum disability level required, benefit generosity, medical assessment, vocational assessment) yields an R-squared of $89 \%$ (adjusted 78\%) and highly significant coefficients. Hence, more than three quarters of the crossnational variation in enrolment rates can be explained by the institutional factors embedded in the five OECD indicators.

\section{Conclusions}

The variation in retirement behavior, old-age labor force participation and disability insurance take-up rates across European countries is striking. In Austria and Italy, the age at which a normal pension is first received is about 6 years earlier than in Denmark and Sweden. In turn, disability insurance enrolment reaches from some 15 percent of individuals aged between 50 and 64 in Denmark, Sweden and the Netherlands to less than 3 percent in Austria and Greece. There is clearly substitution among pathways to retirement, but also an overall effect on labor force participation: In Sweden, 
Denmark and Switzerland, almost $40 \%$ of individuals aged $50+$ classify themselves as working, while only about $20 \%$ do this in Italy and Austria.

While health is an important determinant of earlier retirement, it does not explain the large cross-national variation. This is explained by institutional differences in welfare systems, which clearly affect the distribution and the age pattern of participation to the labor market and of retirement. Countries where early retirement is allowed and/or is generous see a prevalence of early retirees (typically Southern countries, but also Austria and France). Furthermore, in countries where other exit routes are allowed as form of early retirement (disability and unemployment) these substitute for retirement. The most influential institutional variable to explain disability enrolment is the minimum level of disability to obtain full benefits. This variable alone explains more than $60 \%$ of the cross-national variation. It seems to be the most powerful policy variable when countries such as the Netherlands, Denmark and Sweden want to bring their disability insurance enrolment rates closer to the average European level.

There is potentially huge unused labor capacity in countries such as Austria, Italy and France where "healthy" individuals are not in the labor force. Econometric evidence corroborates the early findings: even controlling for health characteristics, age, gender and country effects, the generosity of the social security and pensions systems helps explaining the pattern of retirement (or disability) vis-à-vis work.

The social policy implications are clear. If Europeans want to reduce the already high tax and contribution burdens in the light of population aging, they should exploit the unused capacity of individuals who self-report to enjoy a good functional health status. The current retirement institutions provide generous early retirement options, partially through lenient disability and unemployment insurance rules. Employers and employees cannot be blamed taking these options up, even if the workers are happy and healthy. Rather, it is the task of politicians and lawmakers to align institutions with the necessity to make our social security systems more 
sustainable: to align early retirement ages with an increased life expectancy, to adapt disability insurance to actual functional disability, and to devote unemployment insurance to those who are temporarily out of work and actively search for a new job. 


\section{References}

Blöndal, S. and S. Scarpetta, 1998. "The retirement decision in OECD countries", OECD Economics Department Working Paper.

Börsch-Supan, A., A. Brugiavini, H. Jürges, J. Mackenbach, J. Siegrist and G. Weber, eds., (2005. Health, Ageing and Retirement in Europe: First Results from the Survey of Health, Ageing and Retirement in Europe, MEA Mannheim Research Institute for the Economics of Ageing, Mannheim.

Börsch-Supan, A. and H. Jürges, eds., 2005. The Survey of Health, Ageing and Retirement in Europe - Methodology, MEA Mannheim Research Institute for the Economics of Ageing, Mannheim.

Börsch-Supan, A., 2005. "Work disability and health", in Börsch-Supan et al., eds., Health, Ageing and Retirement in Europe. First Results from SHARE, MEA Mannheim Research Institute for the Economics of Ageing, Mannheim.

European Commission, 2004. Adequate and sustainable pensions, Joint report by the Commission and the Council, European Commission Directorate-General for Employment and Social Affairs Unit E.2, Luxembourg.

Eurostat, 2005. Eurostat Data Archive, http://europa.eu.int/comm/eurostat/

Gruber, J., and D. Wise, eds., 1999. Social Security and Retirement around the World, The University of Chicago Press, Chicago.

Gruber, J., and D. Wise eds., 2004. Social Security and Retirement around the World: Micro Estimation of Early Retirement Incentives, The University of Chicago Press, Chicago.

Gruber, J., and D. Wise, eds., 2007. Social Security and Retirement around the World: Fiscal Implications of Reform, The University of Chicago Press, Chicago.

Gustman, A., and Steinmeier, T. L., 1999. "Effects of Pensions on Savings: Analysis with Data from the Health and Retirement Study", CarnegieRochester Conference Series on Public Policy 50, No. 99: 271-324.

Hurd, M. and K. McGarry, 1997. "The Predictive Validity of Subjective Probabilities of Survival”, NBER working paper 6193.

Klevmarken, N.A., B. Swensson and P. Hesselius, 2006. "The SHARE sampling procedures and calibrated design weights", in Börsch-Supan, A., and H. Jürges, eds., Health, Ageing and Retirement in Europe: Methodology, MEA: Mannheim.

Kohli, M., M. Rein, A.-M. Guillemard, and H. van Gunsteren, eds., 1991. Time for retirement: Comparative studies of early exit from the labor force. Cambridge University Press, Cambridge. 
Munnell, A., A. Sunden and C. Taylor, 2000. "What determines 401(k) Participation and contribution?", Center for Retirement Research, WP200012, Boston College.

OECD, 2003. Transforming Disability into Ability, OECD, Paris.

OECD, 2005. OECD Health Data, OECD, Paris.

Sen, Amemiya, 2002. "Health perception versus observation", British Medical Journal, Vol. 324, pp. 860-861. 
Figure 1: Self-reported economic activity by age

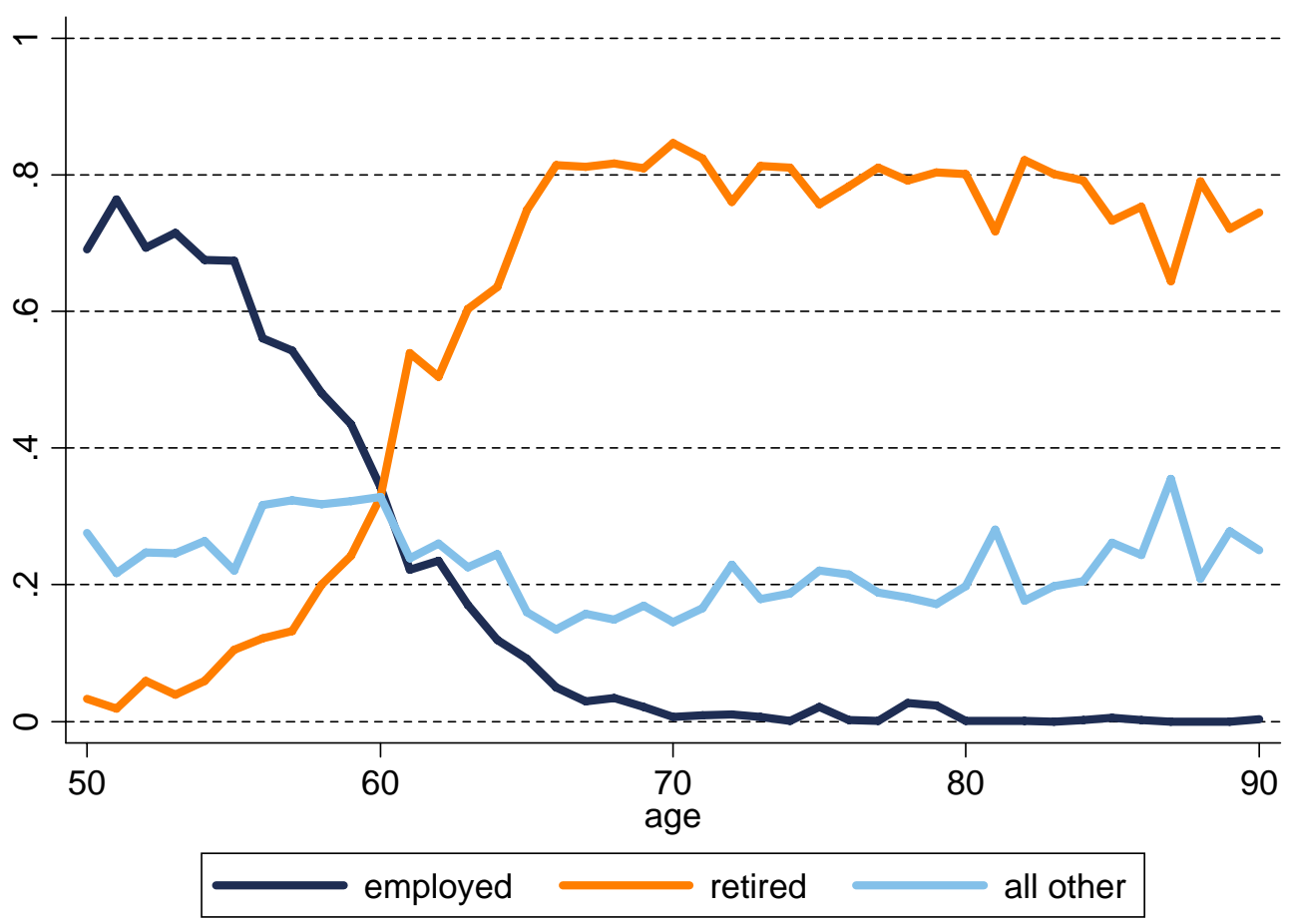

Source: Authors' calculations using SHARE 2004. Population-weighted data. 
Figure 2: Distribution of economically active individuals by gender, age class and country

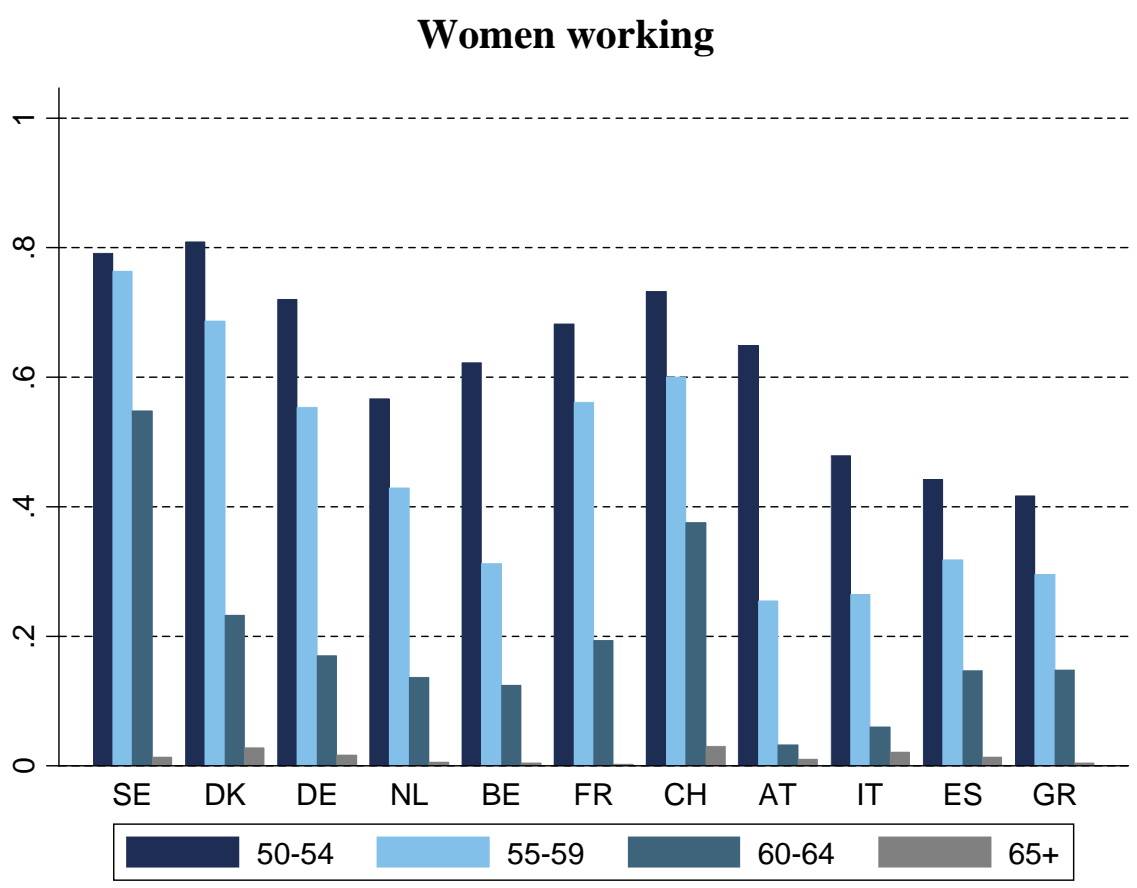

Men working

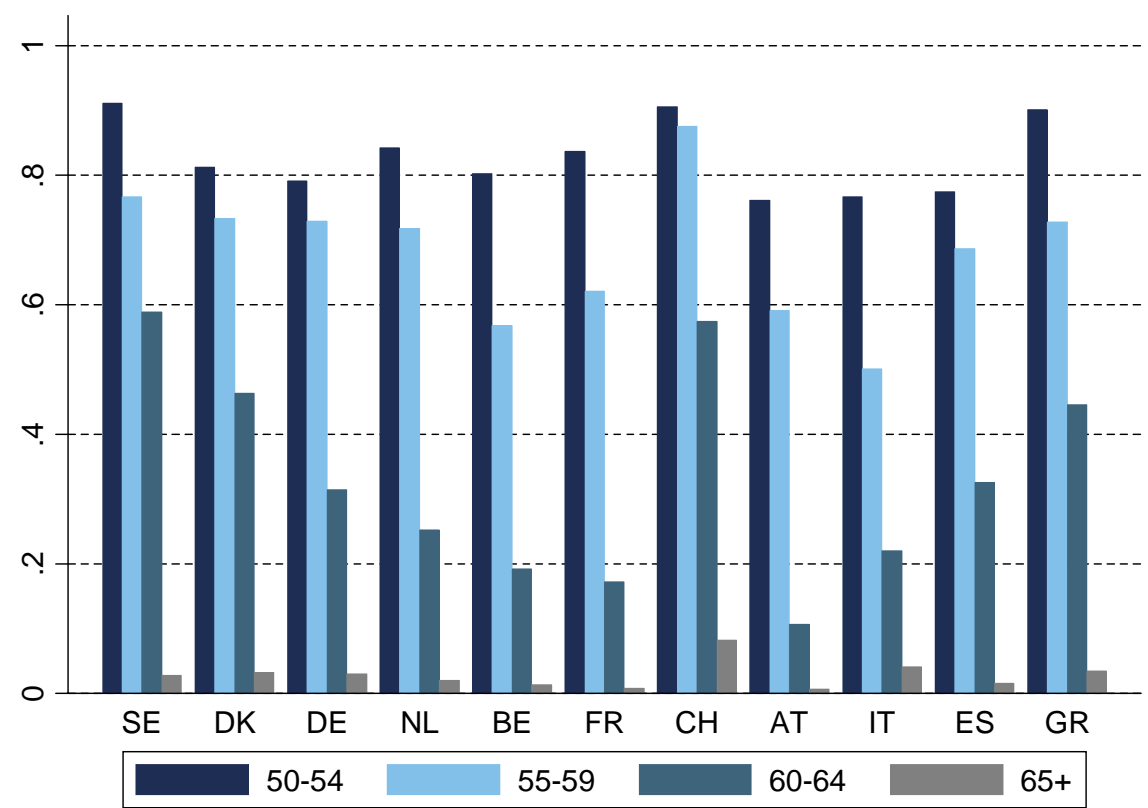

Source: Authors' calculations using SHARE 2004. Population-weighted data. 
Figure 3: Different concepts of economic activity: Worker

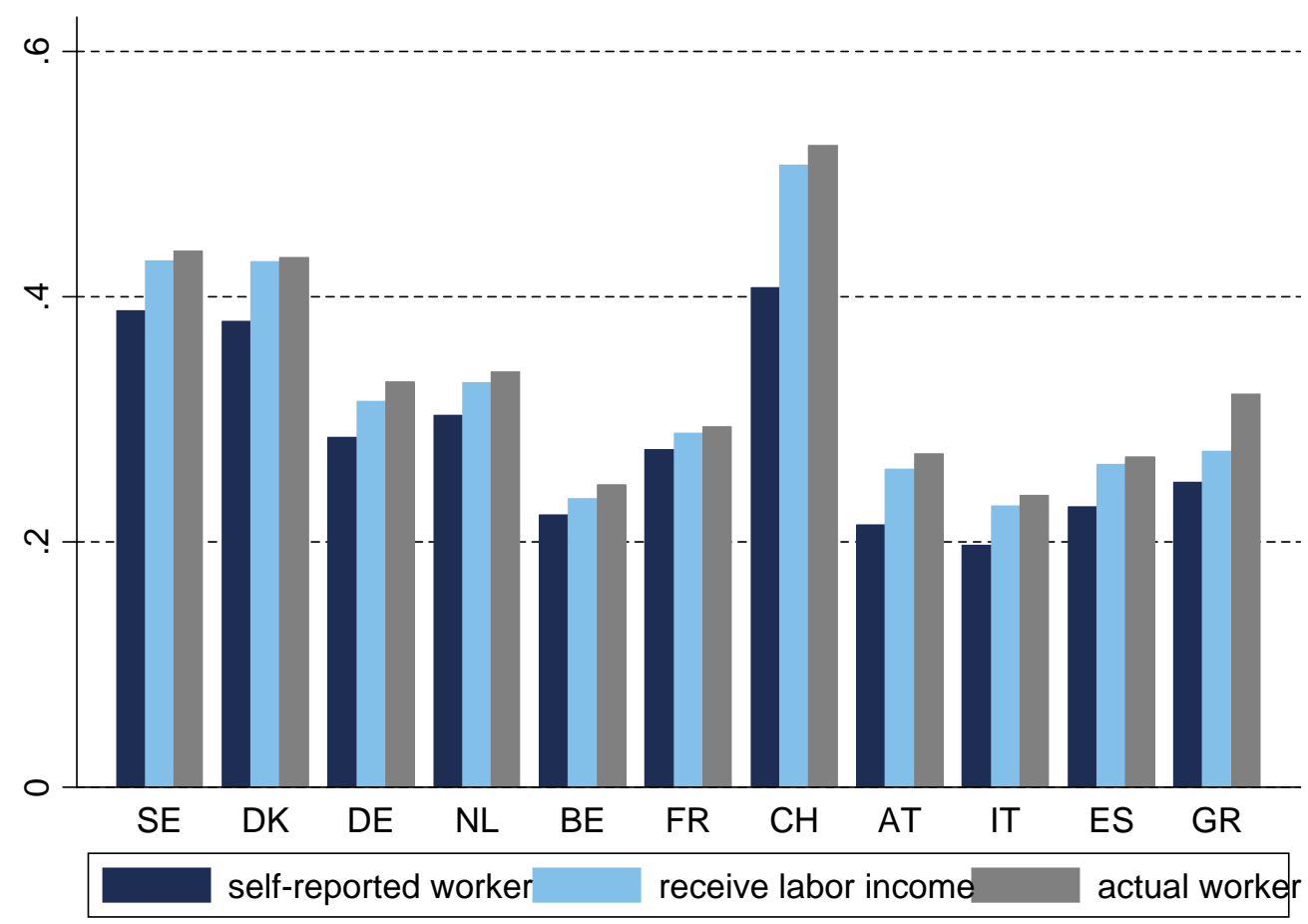

Source: Authors' calculations using SHARE 2004. Population-weighted data. 
Figure 4: Different concepts of economic activity: Retiree

Figure 4a: Retirees and receipt of public/private pension

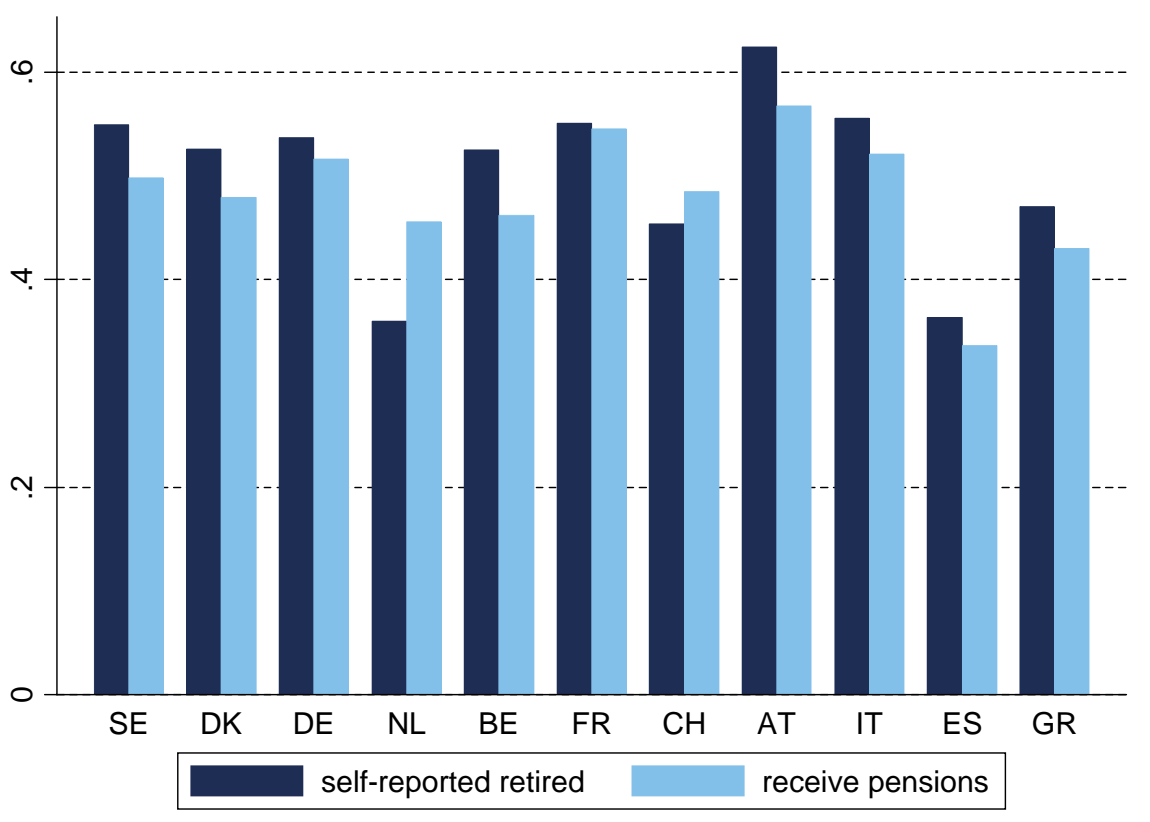

Figure 4b. Retirees and receipt of public/private or survivor pension

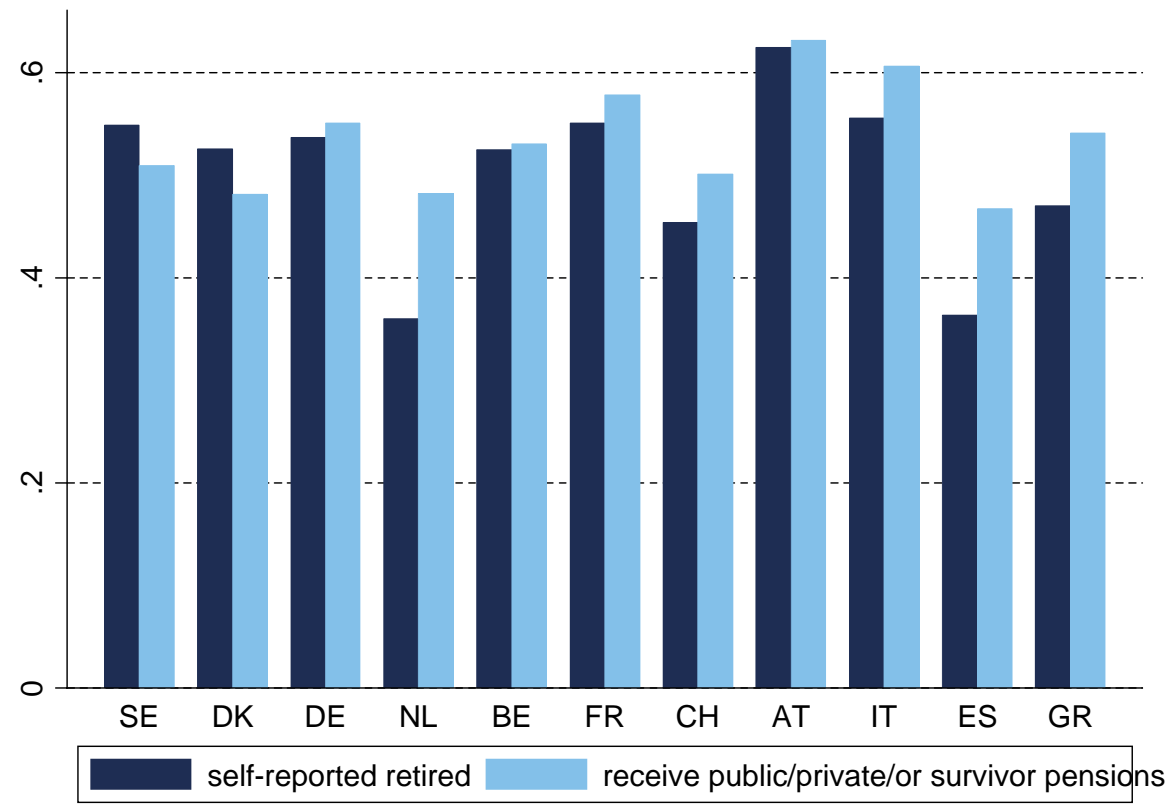


Figure 4: Different concepts of economic activity: Retiree (continued)

Figure 4c: Retirees and receipt of any benefit or pension

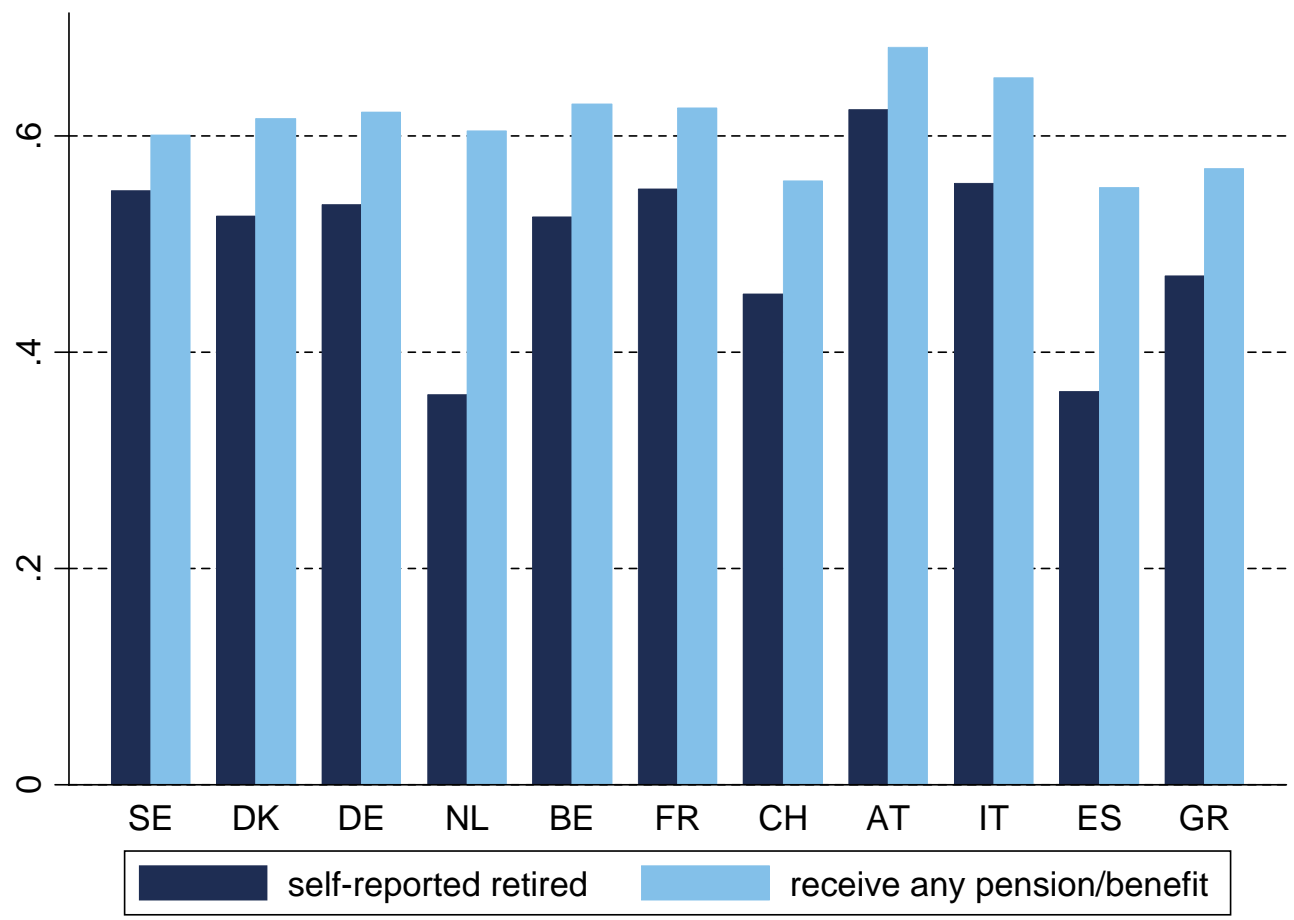

Source: Authors' calculations using SHARE 2004. Population-weighted data. 
Figure 5: Different concepts of economic activity: Unemployed

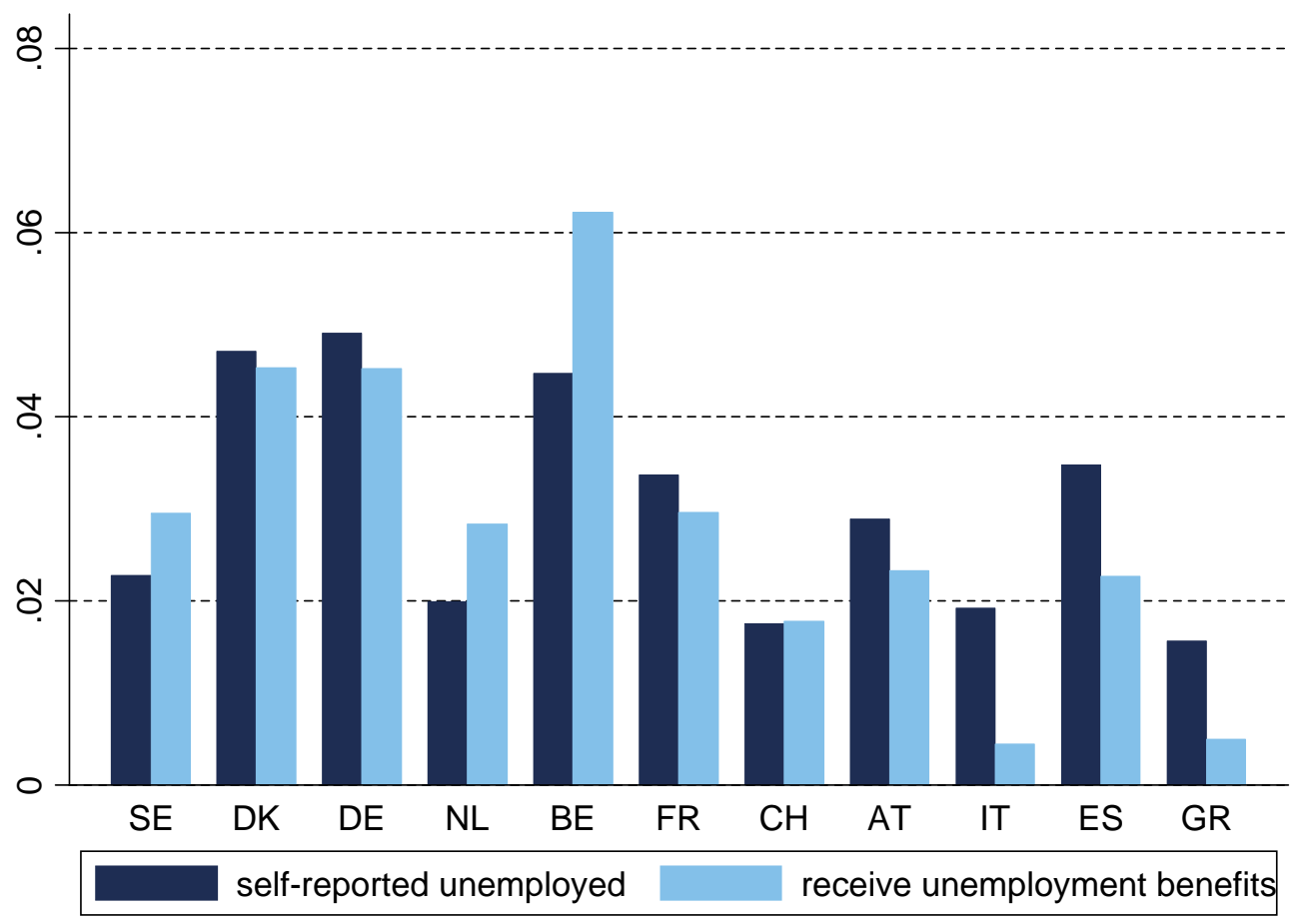

Source: Authors' calculations using SHARE 2004. Population-weighted data. 
Figure 6: Different concepts of economic activity: Disabled

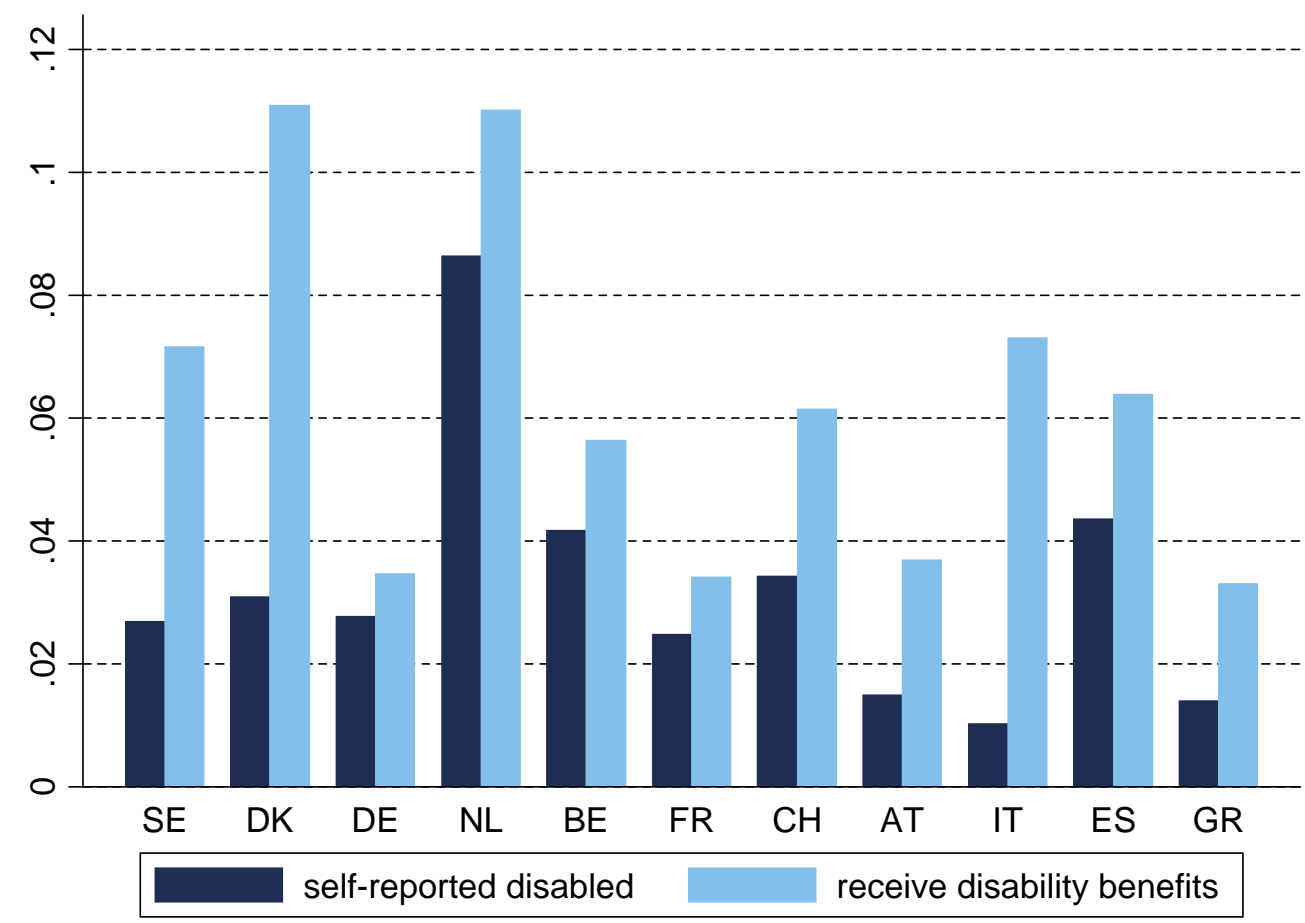

Source: Authors' calculations using SHARE 2004. Population-weighted data. 
Figure 7: Distribution of self-reported and actual economic activity by gender and country

Women

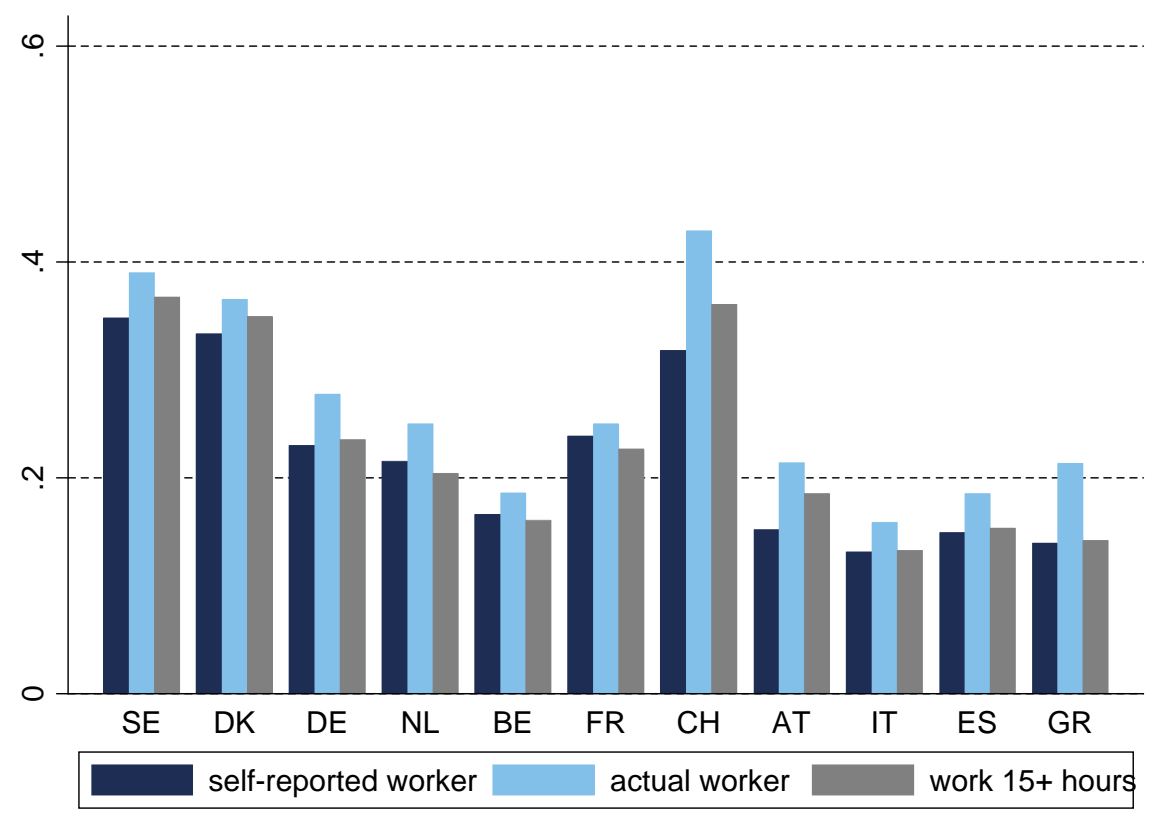

Men

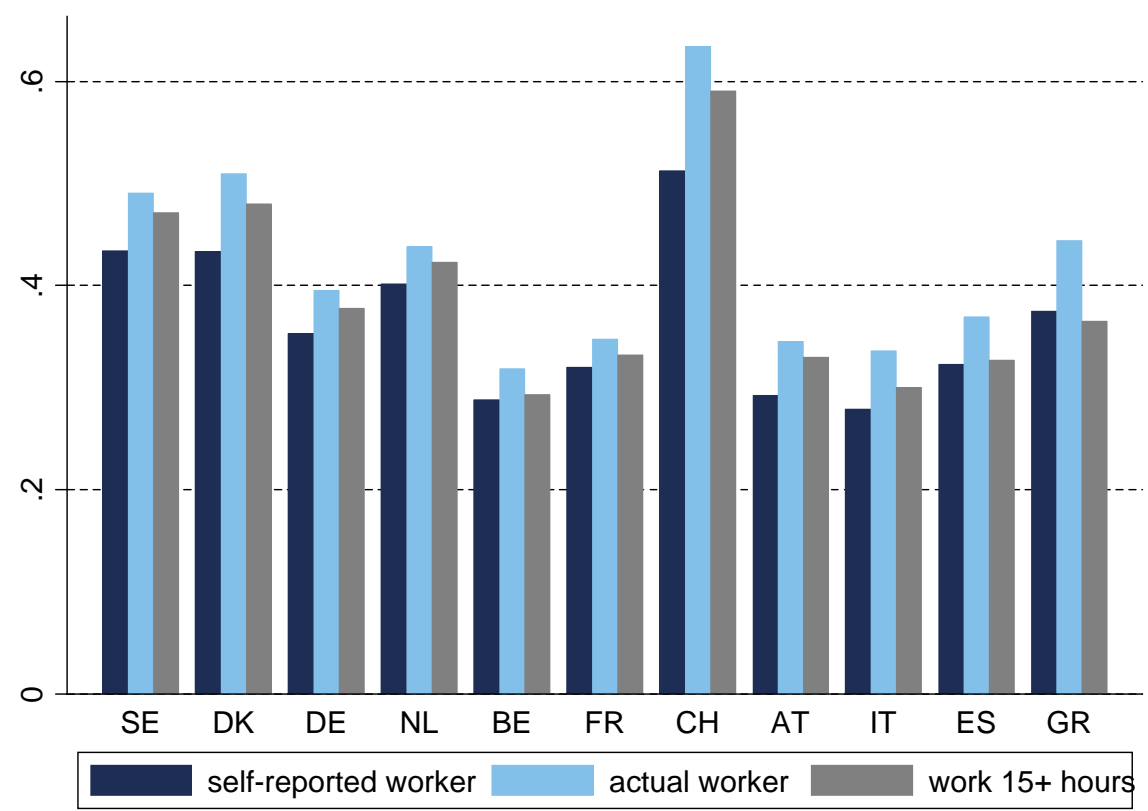

Source: Authors' calculations using SHARE 2004. Population-weighted data. 
Figure 8: Distribution of respondents self-reporting "Disabled" and "Unemployed"

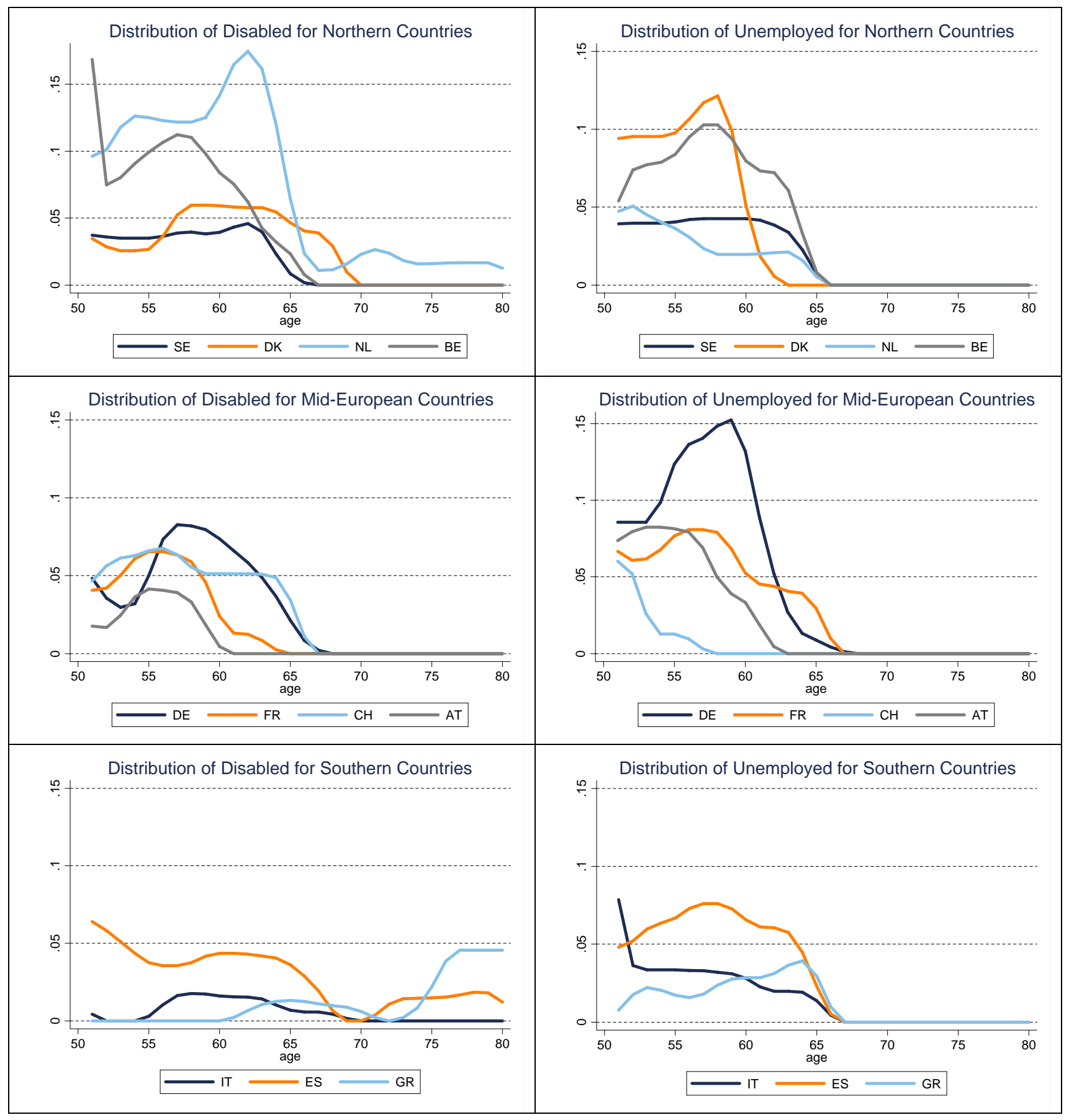

Source: Authors' calculations using SHARE 2004. Population-weighted data. 
Figure 9: Disability insurance enrolment in Europe, 2004

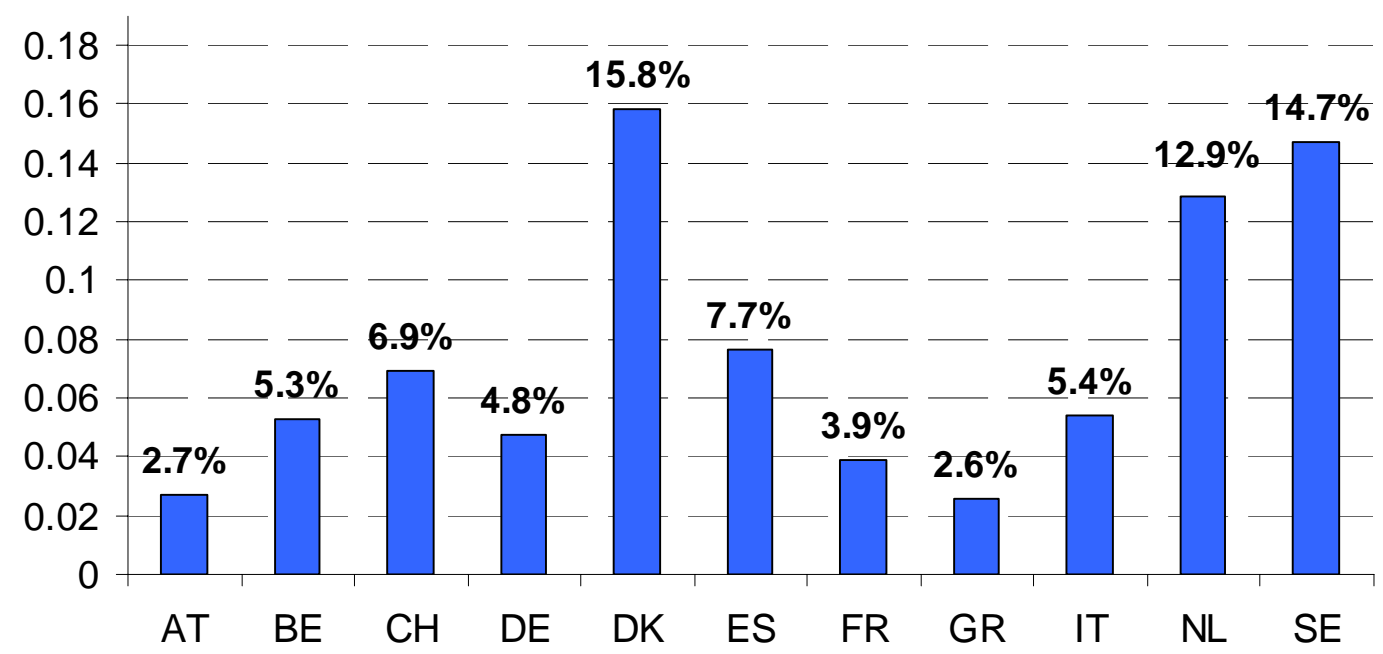

Source: Authors' calculations using SHARE 2004. Age 50-65. Populationweighted data. 
Figure 10. Distribution of self-reported Retirees
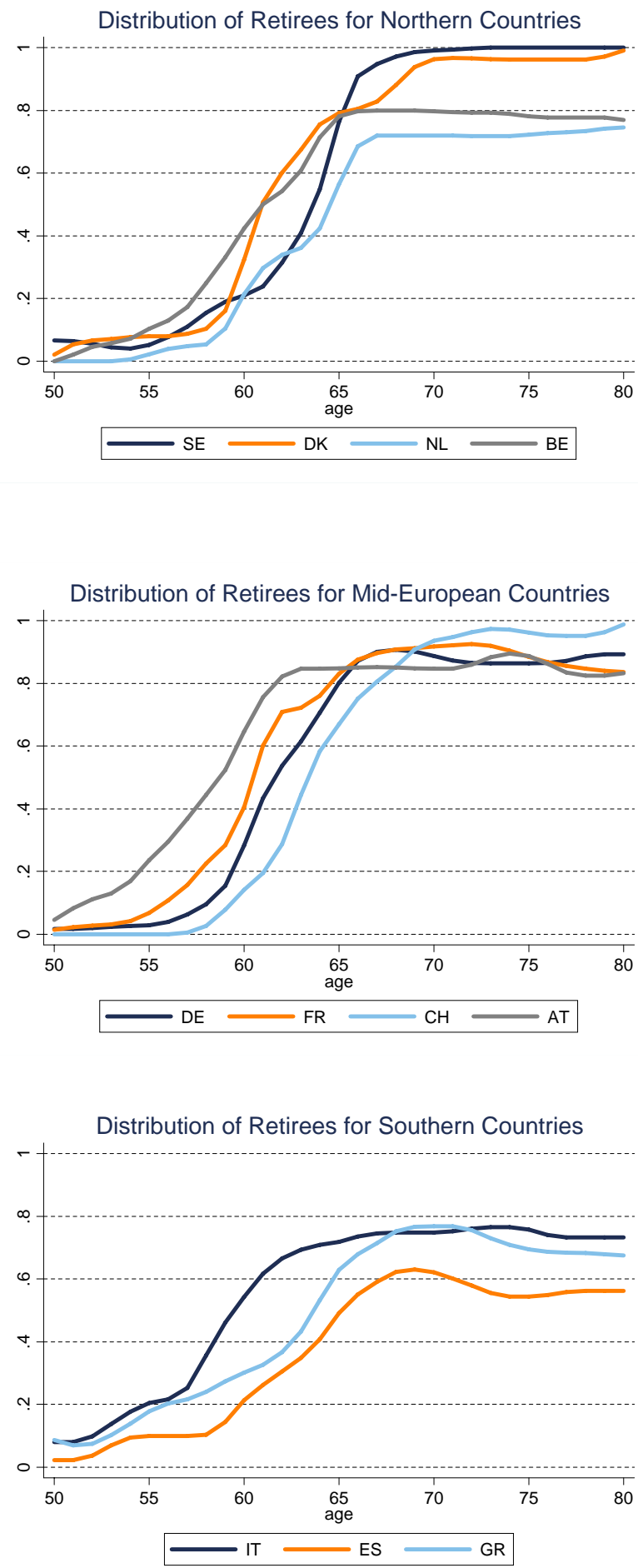

Source: Authors' calculations using SHARE 2004. Population-weighted data. 
Figure 11: Economic activity and physical health

Economic activity of "healthy" respondents

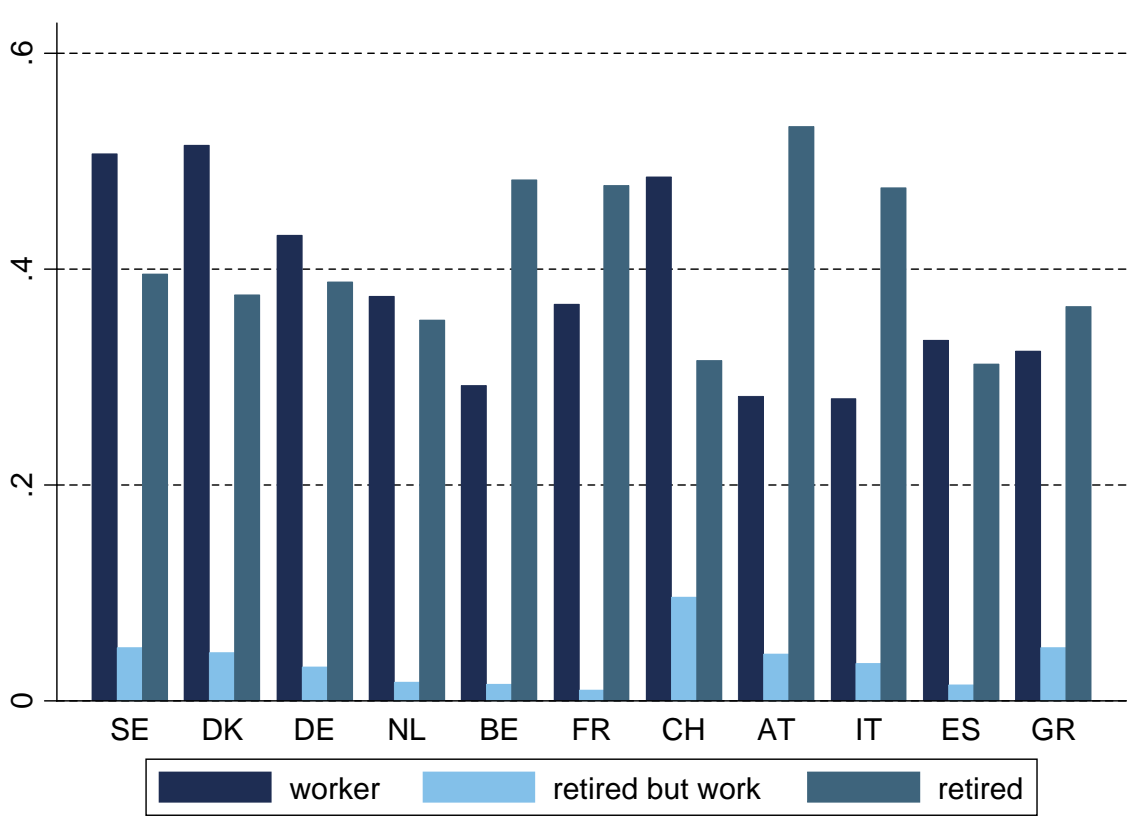

Economic activity of "functioning" respondents

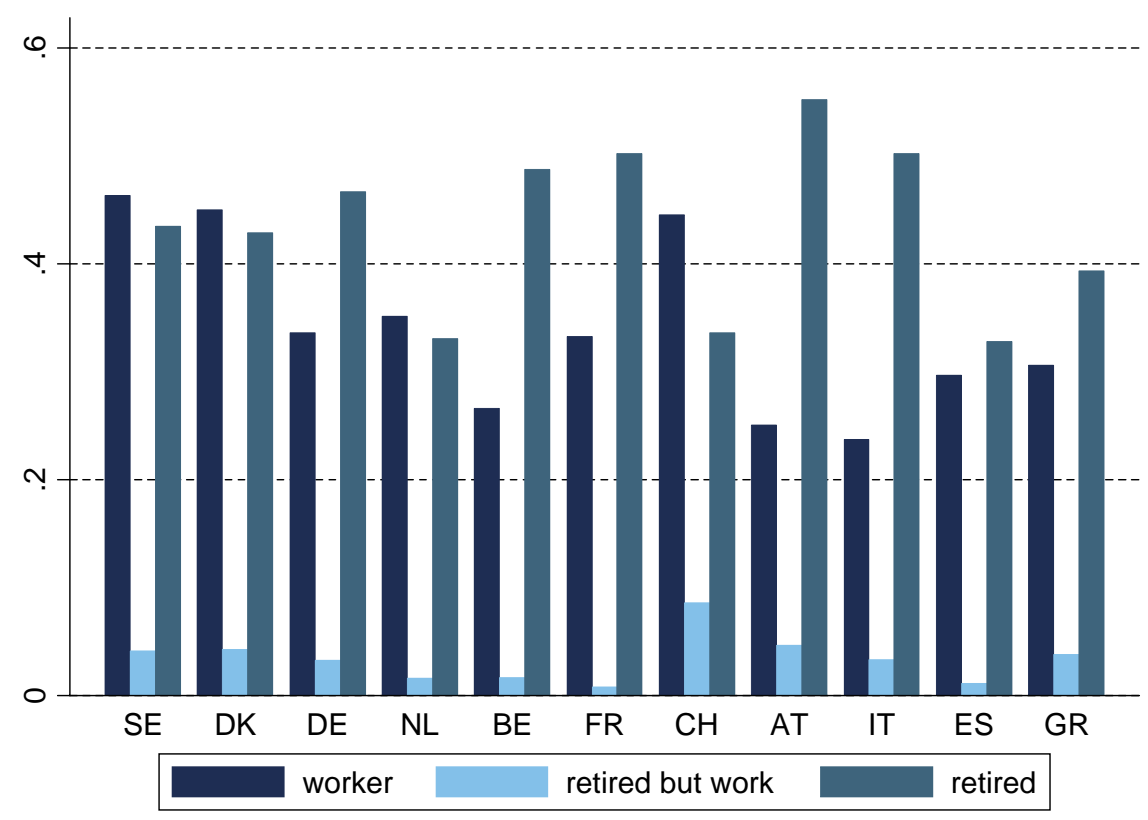

Source: Authors' calculations using SHARE 2004. Population-weighted data. 
Figure 12: Health by disability insurance enrolment, across all countries

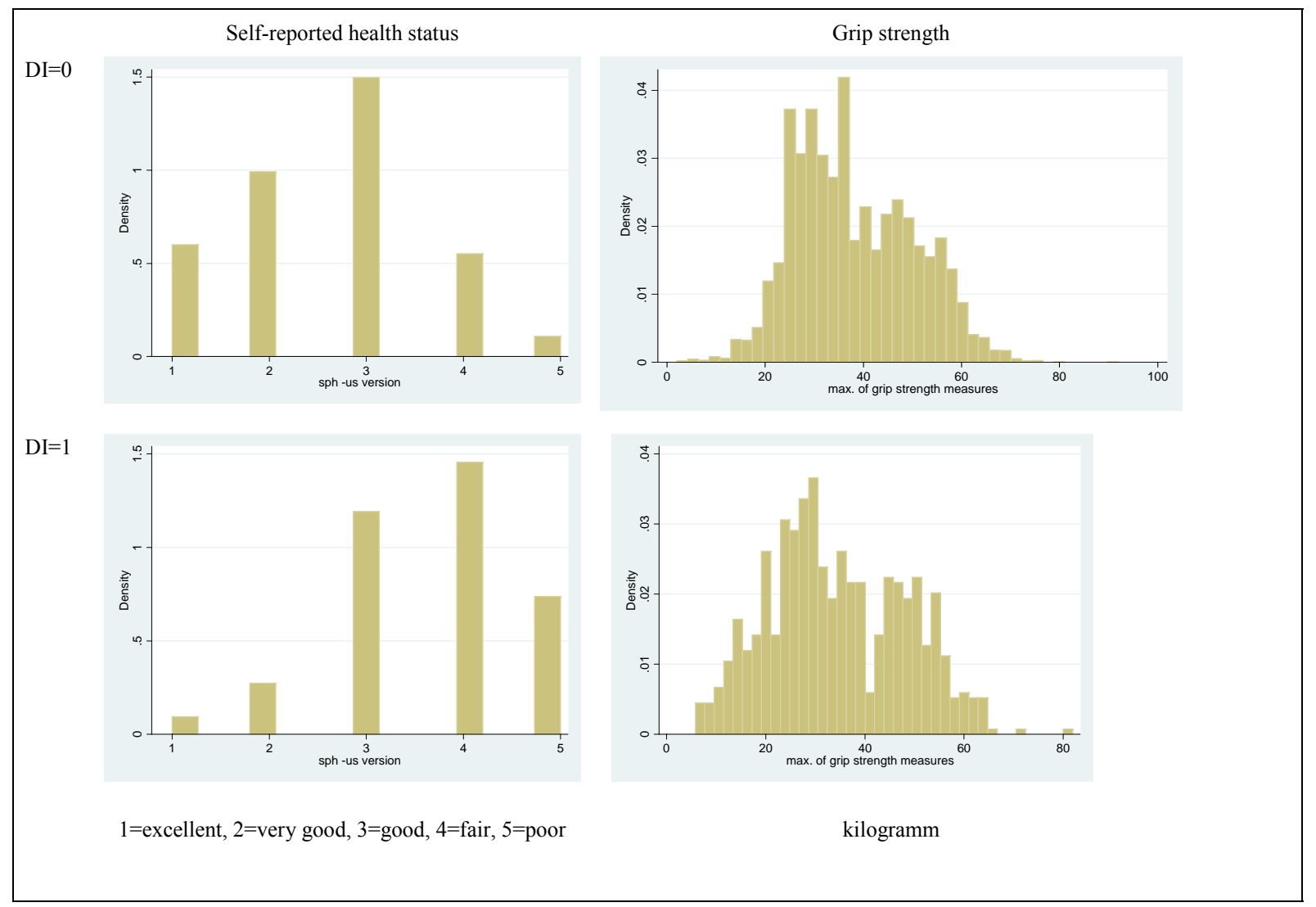

Source: Authors' calculations using SHARE 2004. Population-weighted data. 
Figure 13: Health and disability insurance enrolment, by country

Self-assessed health status

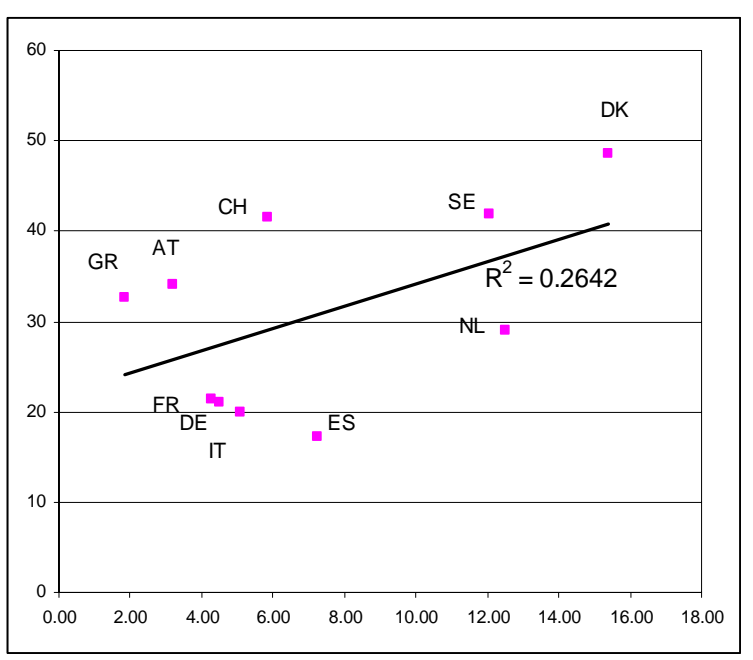

\section{Measured health status}

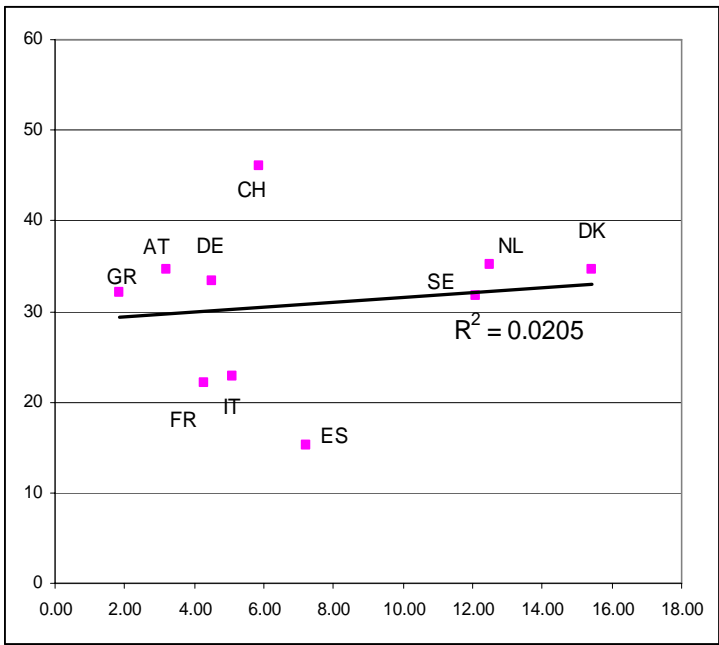

Source: Authors' calculations using SHARE 2004. 
Figure 14: Baseline enrolment rates and counterfactual simulations

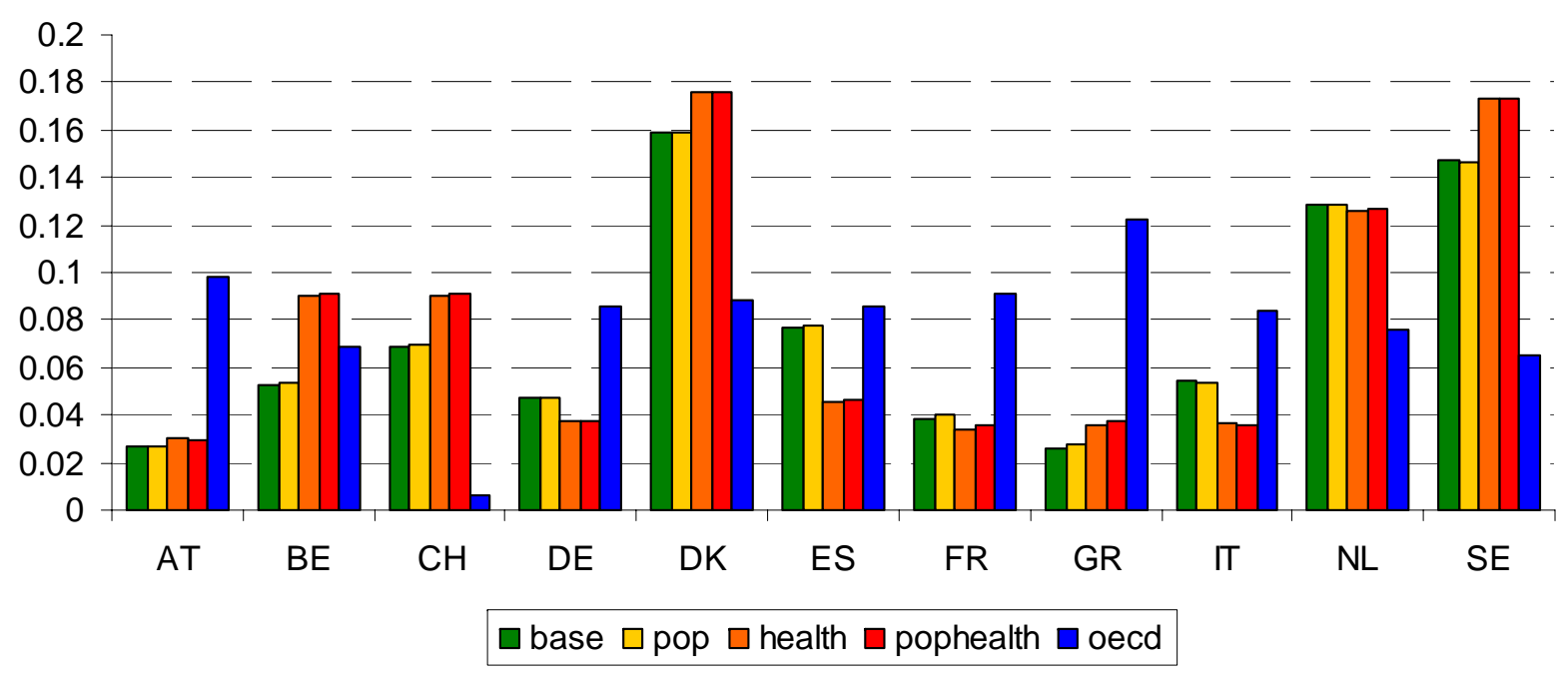

Note: Based on linear regression specification in Table 9. 
Table 1: Self-reported labor market status by country

\begin{tabular}{|c|c|c|c|c|c|c|}
\hline & Employed & Retired & Unemployed & Disabled & Homemaker & Other \\
\hline SE & 38.9 & 54.9 & 2.3 & 2.7 & 1.0 & 0.3 \\
\hline$(\mathrm{N}=2,988)$ & $(1.0)$ & $(1.0)$ & $(0.3)$ & $(0.3)$ & $(0.2)$ & $(0.1)$ \\
\hline DK & 38.0 & 52.6 & 4.7 & 3.1 & 1.6 & 0.0 \\
\hline$(\mathrm{N}=1,695)$ & $(1.3)$ & $(1.3)$ & $(0.6)$ & $(0.4)$ & $(0.3)$ & $(0.0)$ \\
\hline $\mathrm{DE}$ & 28.5 & 53.7 & 4.9 & 2.8 & 10.1 & 0.0 \\
\hline$(\mathrm{N}=2,920)$ & $(0.9)$ & $(1.0)$ & $(0.4)$ & $(0.3)$ & $(0.6)$ & $(0.0)$ \\
\hline NL & 30.3 & 36.0 & 2.0 & 8.6 & 21.3 & 1.8 \\
\hline$(\mathrm{N}=2,850)$ & $(0.9)$ & $(1.0)$ & $(0.3)$ & $(0.6)$ & $(0.8)$ & $(0.3)$ \\
\hline $\mathrm{BE}$ & 22.2 & 52.5 & 4.5 & 4.2 & 16.5 & 0.1 \\
\hline$(\mathrm{N}=3,603)$ & $(0.7)$ & $(0.8)$ & $(0.3)$ & $(0.3)$ & $(0.6)$ & $(0.1)$ \\
\hline $\mathrm{FR}$ & 27.5 & 55.1 & 3.4 & 2.5 & 11.3 & 0.3 \\
\hline$(\mathrm{N}=2,937)$ & $(0.9)$ & $(1.0)$ & $(0.3)$ & $(0.3)$ & $(0.6)$ & $(0.1)$ \\
\hline $\mathrm{CH}$ & 40.7 & 45.4 & 1.8 & 3.4 & 8.7 & 0.0 \\
\hline$(\mathrm{N}=940)$ & (1.6) & $(1.6)$ & $(0.5)$ & $(0.6)$ & $(0.9)$ & $(0.0)$ \\
\hline $\mathrm{AT}$ & 21.4 & 62.4 & 2.9 & 1.5 & 11.8 & 0.0 \\
\hline$(\mathrm{N}=1,840)$ & $(1.0)$ & $(1.2)$ & $(0.4)$ & $(0.3)$ & $(0.8)$ & $(0.0)$ \\
\hline IT & 19.7 & 55.6 & 1.9 & 1.0 & 21.7 & 0.0 \\
\hline$(\mathrm{N}=2,495)$ & $(1.0)$ & (1.2) & $(0.3)$ & $(0.2)$ & $(0.9)$ & $(0.0)$ \\
\hline ES & 22.9 & 36.4 & 3.5 & 4.4 & 32.2 & 0.7 \\
\hline$(\mathrm{N}=2,320)$ & $(1.0)$ & (1.1) & $(0.4)$ & $(0.5)$ & $(1.0)$ & $(0.2)$ \\
\hline GR & 24.9 & 47.0 & 1.6 & 1.4 & 24.9 & 0.3 \\
\hline$(\mathrm{N}=2,654)$ & $(0.8)$ & $(1.0)$ & $(0.3)$ & $(0.2)$ & $(0.9)$ & $(0.1)$ \\
\hline \multicolumn{7}{|c|}{$\begin{array}{l}\text { Source: Authors' calculations using SHARE } 2004 \text {. Based on a sample of } 27,152 \\
\text { individual } 50+\text { respondents who reported their current situation. Percentage values. } \\
\text { Standard errors in parentheses. All figures, except for sample sizes, are population- } \\
\text { weighted. }\end{array}$} \\
\hline
\end{tabular}


Table 2: Self-reported economic activity and income receipt

\begin{tabular}{lcccc}
\hline & $\begin{array}{c}\text { Labor } \\
\text { income }\end{array}$ & Pension & $\begin{array}{c}\text { Unemployment } \\
\text { benefit }\end{array}$ & $\begin{array}{c}\text { Disability } \\
\text { Benefit }\end{array}$ \\
\hline Retired & 4.4 & 89.2 & 0.9 & 4.4 \\
Employed & $(0.2)$ & $(0.4)$ & $(0.1)$ & $(0.3)$ \\
& 97.1 & 2.6 & 1.9 & 1.9 \\
Unemployed & $(0.3)$ & $(0.3)$ & $(0.2)$ & $(0.2)$ \\
& 20.6 & 2.0 & 50.9 & 2.6 \\
Disabled & $(2.0)$ & $(0.6)$ & $(2.4)$ & $(0.5)$ \\
& 11.3 & 10.0 & 2.2 & 67.4 \\
Homemaker & $(1.5)$ & $(1.4)$ & $(0.6)$ & $(2.3)$ \\
& 2.6 & 15.3 & 0.5 & 3.5 \\
Other & $(0.3)$ & $(0.8)$ & $(0.1)$ & $(0.4)$ \\
& 9.4 & 27.3 & 0.3 & 14.6 \\
& $(4.1)$ & $(5.4)$ & $(0.3)$ & $(4.8)$ \\
\hline
\end{tabular}

Source: Authors' calculations using SHARE 2004. Based on a sample of 27,100 individual 50+ respondents who reported their current situation. Percentage values. Standard errors in parentheses. All figures, except for sample sizes, are population-weighted 
Table 3: Percentage of workers and retired by age classes, country and job situation

\begin{tabular}{|c|c|c|c|c|c|c|c|c|c|c|c|}
\hline & SE & DK & $\mathrm{DE}$ & NL & $\mathrm{BE}$ & FR & $\mathrm{CH}$ & AT & ES & IT & GR \\
\hline & \multicolumn{11}{|c|}{ All ages } \\
\hline Worker only & 38.9 & 38.0 & 28.5 & 30.3 & 22.2 & 27.5 & 40.7 & 21.4 & 19.7 & 22.9 & 24.9 \\
\hline Retired but work (any hrs) & 3.8 & 3.8 & 2.8 & 1.5 & 1.6 & 0.8 & 8.7 & 4.6 & 3.0 & 1.2 & 4.4 \\
\hline Retired but work ( $>15$ hrs) & 1.6 & 0.9 & 1.2 & 0.6 & 0.8 & 0.5 & 4.6 & 3.5 & 1.9 & 0.8 & 1.6 \\
\hline \multirow[t]{2}{*}{ Retired only } & 51.0 & 48.8 & 50.8 & 34.5 & 50.9 & 54.3 & 36.7 & 57.8 & 52.5 & 35.2 & 41.1 \\
\hline & \multicolumn{11}{|c|}{ Age $50-54$} \\
\hline Worker only & 85.2 & 81.1 & 75.6 & 71.2 & 71.3 & 75.9 & 81.7 & 70.6 & 61.7 & 60.1 & 64.5 \\
\hline Retired but work (any hrs) & 0.8 & 0.8 & 0.6 & 0.0 & 0.1 & 0.5 & 0.5 & 1.6 & 2.1 & 0.3 & 1.7 \\
\hline Retired but work ( $>15 \mathrm{hrs})$ & 0.6 & 0.0 & 0.3 & 0.0 & 0.1 & 0.3 & 0.5 & 1.2 & 1.2 & 0.3 & 0.7 \\
\hline \multirow[t]{2}{*}{ Retired only } & 4.5 & 6.0 & 1.2 & 0.0 & 4.4 & 2.3 & 0.0 & 8.8 & 7.4 & 4.9 & 6.3 \\
\hline & \multicolumn{11}{|c|}{ Age $55-59$} \\
\hline Worker only & 76.5 & 70.8 & 64.1 & 56.9 & 43.5 & 59.1 & 73.6 & 41.2 & 38.1 & 50.7 & 51.8 \\
\hline Retired but work (any hrs) & 1.3 & 0.9 & 0.7 & 1.1 & 0.7 & 0.8 & 1.3 & 5.3 & 2.0 & 0.8 & 3.7 \\
\hline Retired but work (>15 hrs) & 0.5 & 0.3 & 0.1 & 0.7 & 0.5 & 0.5 & 0.6 & 5.0 & 1.4 & 0.5 & 1.7 \\
\hline \multirow[t]{2}{*}{ Retired only } & 10.6 & 7.9 & 5.6 & 3.3 & 18.3 & 15.5 & 1.0 & 30.8 & 27.8 & 9.3 & 18.2 \\
\hline & \multicolumn{11}{|c|}{ Age 60-64 } \\
\hline Worker only & 56.9 & 34.6 & 23.9 & 19.3 & 15.9 & 18.4 & 47.7 & 6.7 & 13.5 & 23.2 & 28.8 \\
\hline Retired but work (any hrs) & 3.0 & 7.5 & 5.1 & 2.7 & 2.3 & 2.0 & 5.6 & 5.6 & 5.6 & 1.1 & 4.3 \\
\hline Retired but work ( $>15$ hrs) & 1.3 & 1.7 & 2.4 & 1.3 & 1.2 & 1.0 & 2.1 & 4.1 & 3.3 & 0.6 & 1.5 \\
\hline \multirow[t]{2}{*}{ Retired only } & 27.5 & 50.4 & 46.9 & 29.4 & 53.2 & 60.7 & 24.2 & 76.0 & 59.4 & 29.0 & 31.8 \\
\hline & \multicolumn{11}{|c|}{ Age $65-70$} \\
\hline Worker only & 6.7 & 8.0 & 4.4 & 2.1 & 1.8 & 1.3 & 14.9 & 2.7 & 7.4 & 4.3 & 4.9 \\
\hline Retired but work (any hrs) & 12.1 & 11.9 & 5.5 & 2.9 & 2.2 & 1.0 & 23.5 & 7.4 & 4.6 & 1.6 & 7.9 \\
\hline Retired but work ( $>15$ hrs) & 4.9 & 2.8 & 2.3 & 0.9 & 0.6 & 0.5 & 10.0 & 3.5 & 3.4 & 0.9 & 3.6 \\
\hline Retired only & 80.7 & 73.0 & 82.7 & 67.0 & 78.1 & 86.6 & 53.1 & 78.5 & 70.0 & 57.8 & 62.8 \\
\hline $\begin{array}{l}\text { Source: Authors' calculatio } \\
\text { who reported their current } \\
\text { hours or more if they self-r } \\
\text { they worked. All figures, ex }\end{array}$ & $t$ as $r$ & ired ar & 004. E & 1 & 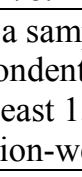 & $\begin{array}{l}\text { hours } \\
\text { ghted }\end{array}$ & f wo & $\mathrm{n}$ th & $50-69$ & esponc & \\
\hline
\end{tabular}


Table 4: Distribution of economically active individuals between full-time and part-time by gender, country and age

\begin{tabular}{|c|c|c|c|c|c|c|c|c|c|c|c|}
\hline \multicolumn{12}{|c|}{ WOMEN } \\
\hline & SE & $\mathrm{DK}$ & $\mathrm{DE}$ & NL & $\mathrm{BE}$ & FR & $\mathrm{CH}$ & $\mathrm{AT}$ & IT & ES & GR \\
\hline \multicolumn{12}{|l|}{ AGE 50-54 } \\
\hline full time & 76.3 & 74.8 & 64.9 & 46.4 & 54.7 & 77.2 & 52.8 & 67.5 & 65.6 & 79.8 & 59.0 \\
\hline part time & 23.7 & 25.2 & 35.1 & 53.6 & 45.3 & 22.8 & 47.2 & 32.5 & 34.4 & 20.2 & 41.0 \\
\hline \multicolumn{12}{|l|}{ AGE 55-59 } \\
\hline full time & 77.3 & 78.1 & 59.6 & 38.2 & 43.8 & 64.2 & 44.8 & 68.2 & 45.8 & 73.4 & 60.5 \\
\hline part time & 22.8 & 21.9 & 40.4 & 61.8 & 56.2 & 35.8 & 55.2 & 31.8 & 54.2 & 26.6 & 39.5 \\
\hline \multicolumn{12}{|l|}{ AGE 60-64 } \\
\hline full time & 64.3 & 68.1 & 53.6 & 27.0 & 50.8 & 70.9 & 46.1 & 57.1 & 57.8 & 67.8 & 61.7 \\
\hline part time & 35.7 & 31.9 & 46.4 & 73.0 & 49.2 & 29.1 & 53.9 & 42.9 & 42.2 & 32.2 & 38.4 \\
\hline \multicolumn{12}{|c|}{ MEN } \\
\hline & SE & DK & $\mathrm{DE}$ & NL & $\mathrm{BE}$ & FR & $\mathrm{CH}$ & $\mathrm{AT}$ & IT & ES & GR \\
\hline \multicolumn{12}{|l|}{ AGE 50-54 } \\
\hline full time & 95.4 & 97.3 & 94.1 & 92.6 & 88.4 & 92.9 & 82.8 & 100.0 & 81.6 & 89.7 & 72.6 \\
\hline part time & 4.6 & 2.7 & 5.9 & 7.4 & 11.6 & 7.1 & 17.2 & 0.0 & 18.4 & 10.3 & 27.4 \\
\hline \multicolumn{12}{|l|}{ AGE 55-59 } \\
\hline full time & 93.5 & 91.2 & 98.2 & 87.6 & 89.4 & 94.8 & 89.1 & 91.8 & 86.3 & 89.4 & 71.6 \\
\hline part time & 6.5 & 8.8 & 1.8 & 12.4 & 10.6 & 5.2 & 10.9 & 8.2 & 13.7 & 10.6 & 28.5 \\
\hline \multicolumn{12}{|l|}{ AGE 60-64 } \\
\hline full time & 85.3 & 90.9 & 98.9 & 69.2 & 76.9 & 87.4 & 87.1 & 83.3 & 83.6 & 78.5 & 72.0 \\
\hline part time & 14.7 & 9.1 & 1.1 & 30.8 & 23.1 & 12.6 & 12.9 & 16.7 & 16.4 & 21.5 & 28.0 \\
\hline
\end{tabular}


Table 5: Average age when receiving a pension for the first time, by gender and country

\begin{tabular}{|c|c|c|c|c|c|c|c|c|c|c|c|}
\hline & SE & DK & $\mathrm{DE}$ & NL & $\mathrm{BE}$ & FR & $\mathrm{CH}$ & $\mathrm{AT}$ & IT & ES & GR \\
\hline & \multicolumn{11}{|c|}{ FEMALE } \\
\hline \multirow{3}{*}{$\begin{array}{l}\text { Public and private old } \\
\text { age and early } \\
\text { retirement pensions } \\
\text { Disability and } \\
\text { invalidity/incapacity } \\
\text { pensions }\end{array}$} & 63.9 & 65.9 & 61.1 & 63.7 & 59.6 & 60.5 & 62.2 & 56.9 & 58.0 & 62.6 & 60.6 \\
\hline & 54.6 & 49.6 & 50.3 & 45.9 & 48.2 & 48.0 & 48.3 & 53.3 & 52.4 & 51.5 & 52.5 \\
\hline & \multicolumn{11}{|c|}{ MALE } \\
\hline $\begin{array}{l}\text { Public and private old } \\
\text { age and early } \\
\text { retirement pensions }\end{array}$ & 64.1 & 65.0 & 61.8 & 62.0 & 61.4 & 59.5 & 64.1 & 58.8 & 59.4 & 61.9 & 60.5 \\
\hline $\begin{array}{l}\text { Disability and } \\
\text { invalidity/incapacity } \\
\text { pensions }\end{array}$ & 56.6 & 49.5 & 51.8 & 47.4 & 49.2 & 47.1 & 56.0 & 50.8 & 52.2 & 50.1 & 52.7 \\
\hline $\begin{array}{l}\text { Source: Authors' calcu } \\
\text { based on a sample of } 9 \\
1102 \text { individuals. All } \mathrm{f}\end{array}$ & $\begin{array}{l}\text { ions u } \\
0 \text { indi } \\
\text { Ires, e }\end{array}$ & $\mathrm{g} \mathrm{SH}$ & impl & $\begin{array}{l}\text { Publ } \\
\text { and in } \\
\text { zes, a1 }\end{array}$ & $\mathrm{adp}$ & $\begin{array}{l}\text { te olc } \\
\text { apaci } \\
\text { on-we }\end{array}$ & $\begin{array}{l}\text { ge anc } \\
\text { pensi } \\
\text { ted. }\end{array}$ & rly r & ed on & $\begin{array}{l}\text { nsior } \\
\text { amp }\end{array}$ & \\
\hline
\end{tabular}


Table 6: Reasons for retirement by gender and country

WOMEN

\begin{tabular}{|c|c|c|c|c|c|c|c|c|c|c|c|}
\hline & SE & DK & $\mathrm{DE}$ & NL & $\mathrm{BE}$ & FR & $\mathrm{CH}$ & AT & IT & ES & GR \\
\hline \multicolumn{12}{|c|}{ Age 55-59 } \\
\hline Eligible & 0.0 & 0.0 & 7.4 & 0.0 & 9.9 & 61.1 & 51.4 & 66.2 & 65.0 & 17.1 & 39.9 \\
\hline Early-preretirement & 7.9 & 20.2 & 50.3 & 39.9 & 19.7 & 13.0 & 48.6 & 9.5 & 10.8 & 0.0 & 25.4 \\
\hline Health-problems & 92.2 & 74.8 & 21.4 & 0.0 & 21.4 & 5.3 & 0.0 & 18.9 & 26.5 & 69.5 & 7.4 \\
\hline Enjoy life & 0.0 & 5.0 & 7.4 & 0.0 & 10.6 & 15.1 & 0.0 & 2.7 & 10.8 & 0.0 & 24.9 \\
\hline Other & 2.2 & 0.0 & 10.3 & 60.1 & 9.2 & 9.3 & 0.0 & 1.4 & 6.7 & 0.0 & 0.0 \\
\hline \multicolumn{12}{|c|}{ Age $60-64$} \\
\hline Eligible & 4.0 & 15.5 & 45.1 & 13.2 & 32.9 & 44.1 & 68.7 & 66.9 & 70.7 & 4.3 & 59.3 \\
\hline Early-preretirement & 20.1 & 29.1 & 31.9 & 31.6 & 20.4 & 21.0 & 15.5 & 12.2 & 6.4 & 28.3 & 12.3 \\
\hline Health-problems & 63.5 & 41.3 & 14.1 & 7.9 & 20.2 & 16.2 & 5.4 & 14.0 & 5.4 & 43.3 & 11.0 \\
\hline Enjoy life & 11.3 & 22.3 & 6.9 & 5.3 & 12.6 & 9.9 & 10.4 & 8.7 & 13.3 & 2.8 & 10.3 \\
\hline Other & 3.0 & 2.0 & 12.1 & 13.3 & 11.5 & 12.0 & 0.0 & 1.8 & 3.2 & 0.0 & 5.5 \\
\hline \multicolumn{12}{|c|}{ Age $65+$} \\
\hline Eligible & 54.5 & 44.3 & 59.3 & 30.0 & 36.1 & 48.0 & 66.8 & 65.4 & 67.6 & 53.6 & 69.8 \\
\hline Early-preretirement & 14.3 & 17.6 & 11.0 & 15.9 & 13.6 & 10.1 & 2.6 & 4.3 & 3.6 & 7.4 & 4.2 \\
\hline Health-problems & 23.2 & 17.2 & 12.4 & 11.5 & 13.6 & 11.0 & 6.0 & 15.9 & 15.1 & 22.0 & 11.1 \\
\hline Enjoy life & 5.9 & 16.5 & 12.6 & 15.1 & 19.0 & 18.1 & 7.2 & 10.9 & 14.6 & 5.0 & 7.8 \\
\hline Other & 7.4 & 5.5 & 13.0 & 26.9 & 17.2 & 14.4 & 15.6 & 2.3 & 2.2 & 4.8 & 3.6 \\
\hline
\end{tabular}

MEN

\begin{tabular}{|c|c|c|c|c|c|c|c|c|c|c|c|}
\hline & SE & DK & $\mathrm{DE}$ & NL & $\mathrm{BE}$ & FR & $\mathrm{CH}$ & AT & ES & IT & GR \\
\hline \multicolumn{12}{|c|}{ Age 55-59 } \\
\hline Eligible & 5.7 & 0.0 & 5.8 & 15.4 & 9.5 & 52.4 & 100.0 & 30.8 & 66.5 & 22.8 & 69.1 \\
\hline Early-preretirement & 10.8 & 23.5 & 43.7 & 50.0 & 39.2 & 36.1 & 66.7 & 23.1 & 14.2 & 18.4 & 9.6 \\
\hline Health-problems & 67.3 & 69.7 & 52.5 & 0.0 & 7.4 & 8.5 & 0.0 & 46.2 & 16.1 & 36.3 & 14.2 \\
\hline Enjoy life & 5.4 & 0.0 & 5.8 & 7.7 & 1.0 & 10.1 & 0.0 & 2.6 & 4.1 & 0.0 & 7.1 \\
\hline Other & 3.2 & 0.0 & 12.1 & 5.3 & 6.4 & 5.7 & 0.0 & 0.0 & 1.3 & 0.0 & 0.0 \\
\hline \multicolumn{12}{|c|}{ Age $60-64$} \\
\hline Eligible & 12.8 & 27.1 & 27.6 & 20.2 & 34.5 & 60.4 & 30.1 & 57.6 & 78.9 & 19.3 & 73.6 \\
\hline Early-preretirement & 41.4 & 38.0 & 42.0 & 38.8 & 35.1 & 19.4 & 31.9 & 16.7 & 9.3 & 35.9 & 12.3 \\
\hline Health-problems & 42.4 & 33.5 & 30.6 & 5.0 & 8.4 & 16.6 & 4.3 & 28.5 & 6.9 & 33.8 & 7.3 \\
\hline Enjoy life & 4.7 & 16.8 & 1.4 & 2.9 & 6.3 & 0.8 & 17.4 & 2.1 & 2.9 & 2.5 & 2.2 \\
\hline Other & 13.0 & 3.1 & 2.8 & 12.7 & 6.8 & 12.0 & 17.8 & 0.0 & 0.9 & 0.0 & 0.0 \\
\hline \multicolumn{12}{|c|}{ Age $65+$} \\
\hline Eligible & 52.4 & 43.8 & 57.5 & 31.4 & 46.9 & 63.7 & 65.4 & 76.0 & 82.9 & 60.6 & 86.3 \\
\hline Early-preretirement & 22.3 & 31.6 & 24.0 & 41.8 & 29.3 & 21.0 & 15.2 & 6.6 & 6.0 & 18.4 & 1.8 \\
\hline Health-problems & 18.7 & 22.7 & 21.3 & 14.1 & 14.1 & 11.0 & 8.5 & 17.5 & 9.7 & 14.9 & 8.4 \\
\hline Enjoy life & 3.5 & 13.7 & 1.2 & 3.9 & 2.6 & 2.0 & 7.9 & 0.9 & 2.6 & 2.1 & 0.8 \\
\hline Other & 4.8 & 2.0 & 5.2 & 12.6 & 7.5 & 7.1 & 8.2 & 0.4 & 0.8 & 1.9 & 0.5 \\
\hline
\end{tabular}


Table 7: Retirement: Is it a Relief or a Concern?

\begin{tabular}{|c|c|c|c|c|}
\hline & Relief & Concern & Neither & Both \\
\hline & 60.9 & 6.9 & 19.8 & 12.4 \\
\hline \multirow[t]{2}{*}{ SE } & (1.3) & $(0.7)$ & (1.1) & $(0.9)$ \\
\hline & 58.3 & 7.6 & 23.2 & 10.8 \\
\hline \multirow[t]{2}{*}{ DK } & (1.8) & $(1.0)$ & (1.5) & $(1.2)$ \\
\hline & 61.9 & 6.0 & 22.6 & 9.5 \\
\hline \multirow[t]{2}{*}{$\mathrm{DE}$} & (1.4) & $(0.6)$ & (1.2) & $(0.9)$ \\
\hline & 36.3 & 8.3 & 51.9 & 3.4 \\
\hline \multirow[t]{2}{*}{ NL } & (1.7) & $(1.0)$ & (1.7) & $(0.6)$ \\
\hline & 46.1 & 10.4 & 36.9 & 6.7 \\
\hline \multirow[t]{2}{*}{$\mathrm{BE}$} & (1.2) & $(0.7)$ & (1.2) & $(0.6)$ \\
\hline & 54.2 & 8.0 & 33.3 & 4.4 \\
\hline \multirow[t]{2}{*}{ FR } & (1.3) & $(0.7)$ & (1.2) & $(0.6)$ \\
\hline & 70.5 & 2.9 & 22.5 & 4.1 \\
\hline \multirow[t]{2}{*}{$\mathrm{CH}$} & $(2.2)$ & $(0.8)$ & $(2.0)$ & $(1.0)$ \\
\hline & 70.4 & 2.5 & 22.0 & 5.2 \\
\hline \multirow[t]{2}{*}{ AT } & (1.3) & $(0.5)$ & (1.2) & $(0.7)$ \\
\hline & 54.6 & 11.2 & 30.2 & 4.0 \\
\hline \multirow[t]{2}{*}{ IT } & (1.6) & $(1.0)$ & $(1.5)$ & $(0.6)$ \\
\hline & 67.6 & 11.9 & 14.4 & 6.2 \\
\hline \multirow[t]{2}{*}{ ES } & (1.8) & (1.3) & (1.4) & $(0.9)$ \\
\hline & 57.2 & 13.5 & 19.1 & 10.3 \\
\hline GR & $(1.5)$ & (1.1) & $(1.2)$ & $(0.9)$ \\
\hline & sed o & SHARE & $\begin{array}{l}\text { centage } \\
\text { iduals. }\end{array}$ & $\begin{array}{l}\text { d errors i } \\
\text {, except }\end{array}$ \\
\hline
\end{tabular}


Table 8: Probit Estimates of the Decision to Retire - Marginal Effects

(1)

(2)

(3)

(4)
Respondent is male

(Age/10)

(Age/10) squared

Respondent is married

Years of schooling

No functional limitation

IADL-limited

Subjective survival probability

Subjective lifespan

SSWrel

SE

DK

NL

BE

FR

$\mathrm{CH}$

AT

IT

ES

GR

$\begin{array}{rrrr}-0.022 & -0.022 & -0.034 & -0.033 \\ (0.012) & (0.012) & (0.013) & (0.013) \\ -1.167 & -1.418 & -1.313 & -1.495 \\ (0.343) & (0.335) & (0.369) & (0.363) \\ 0.175 & 0.192 & 0.192 & 0.204 \\ (0.029) & (0.028) & (0.031) & (0.031) \\ -0.008 & -0.008 & 0.021 & 0.021 \\ (0.016) & (0.016) & (0.017) & (0.017) \\ -0.016 & -0.016 & -0.014 & -0.014 \\ (0.001) & (0.001) & (0.002) & (0.002) \\ -0.076 & -0.077 & -0.103 & -0.103 \\ (0.013) & (0.013) & (0.014) & (0.014) \\ 0.112 & 0.113 & 0.122 & 0.123 \\ (0.023) & (0.022) & (0.024) & (0.024) \\ -0.145 & & -0.106 & \\ (0.024) & & (0.026) & \\ & -0.008 & & -0.006 \\ & (0.001) & & (0.002) \\ 0.027 & 0.026 & 0.021 & 0.020 \\ (0.021) & (0.021) & (0.012) & (0.012)\end{array}$

$\begin{array}{ll}-0.199 & -0.199\end{array}$

$(0.023) \quad(0.023)$

$-0.095 \quad-0.096$

$(0.028) \quad(0.028)$

$-0.084 \quad-0.085$

$(0.025) \quad(0.024)$

$0.139 \quad 0.139$

$(0.023) \quad(0.023)$

$0.094 \quad 0.095$

$(0.024) \quad(0.024)$

$-0.257 \quad-0.257$

$(0.030) \quad(0.030)$

$0.309 \quad 0.309$

$(0.020) \quad(0.020)$

$0.207 \quad 0.207$

$(0.026) \quad(0.026)$

$-0.122 \quad-0.123$

$(0.035) \quad(0.035)$

$0.074 \quad 0.074$

$(0.029) \quad(0.029)$

\begin{tabular}{lrrrr}
\hline Mean of dependent variable & 0.487 & 0.487 & 0.487 & 0.487 \\
Number of observations & 13244 & 13244 & 13244 & 13244 \\
\hline
\end{tabular}

Based on sample of respondents who reported to be working or retired. Dependent variable: 1 if retired, 0 otherwise..Robust standard errors in parentheses. 
Table 9 : Regression results disability insurance enrolment

\begin{tabular}{|c|c|c|c|c|c|c|}
\hline & Probit & Z & Weibull & $\mathrm{z}$ & Linear & $\mathrm{T}$ \\
\hline Female & -0.661 & -1.91 & 0.430 & -1.71 & -0.078 & -1.39 \\
\hline Age $<55$ & -1.068 & -0.58 & 2.602 & 0.19 & -0.094 & -0.31 \\
\hline Age $>60$ & 0.385 & 0.1 & 12.949 & 0.49 & 0.123 & 0.25 \\
\hline Age-lin1 & 0.027 & 2.05 & 0.940 & -1.84 & 0.003 & 2.29 \\
\hline Age-lin2 & 0.006 & 0.15 & 0.955 & -0.56 & 0.001 & 0.12 \\
\hline Age-lin3 & -0.006 & -0.09 & 0.960 & -0.45 & -0.002 & -0.22 \\
\hline SRH-excellent & -0.896 & -6.86 & 0.141 & -8.14 & -0.063 & -2.62 \\
\hline SRH-very good & -0.534 & -4.28 & 0.324 & -7.5 & -0.041 & -2.15 \\
\hline SRH-fair & -0.007 & -0.06 & 1.417 & 0.68 & -0.192 & -4.73 \\
\hline SRH-poor & 0.361 & 2.49 & 2.206 & 1.55 & -0.078 & -1.53 \\
\hline CES-D (sum) & 0.058 & 4.88 & 1.087 & 4.33 & 0.008 & 2.84 \\
\hline ADL (sum) & 0.054 & 1.33 & 1.052 & 1.04 & 0.022 & 1.9 \\
\hline IADL (sum) & 0.221 & 4.6 & 1.257 & 4.42 & 0.061 & 3.7 \\
\hline Coverage & 0.039 & 0.68 & 1.320 & 1.96 & -0.023 & -2.19 \\
\hline Min. benefits & 0.361 & 4.39 & 1.992 & 3.09 & 0.036 & 2.39 \\
\hline Full benefits & -0.184 & -2.18 & 0.616 & -2.87 & 0.003 & 0.26 \\
\hline Generosity & -0.329 & -5.03 & 0.546 & -2.71 & -0.028 & -3.12 \\
\hline Permanent & 0.049 & 1.87 & 1.175 & 2.59 & -0.006 & -0.81 \\
\hline Medical & 0.069 & 2.71 & 1.106 & 1.46 & 0.006 & 1.4 \\
\hline Vocational & -0.121 & -1.79 & 0.943 & -0.31 & -0.040 & -3.29 \\
\hline UI-Benefits & 0.106 & 4.02 & 1.120 & 1.3 & 0.022 & 3.02 \\
\hline covg_fem & 0.205 & 4.87 & 1.447 & 4.46 & 0.027 & 3.18 \\
\hline minl_fem & 0.015 & 0.15 & 1.025 & 0.14 & 0.000 & -0.03 \\
\hline Full_fem & -0.086 & -1.17 & 0.810 & -1.71 & -0.005 & -0.52 \\
\hline geno_fem & -0.018 & -0.23 & 0.908 & -0.53 & -0.002 & -0.2 \\
\hline covg_old & -0.032 & -0.92 & 0.922 & -0.99 & 0.000 & 0 \\
\hline minl_old & -0.118 & -1.65 & 0.819 & -1.08 & -0.003 & -0.37 \\
\hline full_old & -0.048 & -1.12 & 0.882 & -1.25 & -0.010 & -1.94 \\
\hline geno_old & 0.173 & 2.72 & 1.353 & 1.6 & 0.011 & 1.32 \\
\hline covg_hfpoor & 0.110 & 5.27 & 1.008 & 0.09 & 0.078 & 14.63 \\
\hline minl_hfpoor & 0.091 & 2.12 & 0.918 & -0.45 & 0.072 & 7.95 \\
\hline full_hfpoor & 0.063 & 1.32 & 1.430 & 2.67 & -0.024 & -2.88 \\
\hline geno_hfpoor & -0.036 & -0.95 & 1.111 & 0.53 & -0.030 & -7.68 \\
\hline Constant & -1.827 & -0.71 & 1.256 & 35.76 & 0.182 & 0.49 \\
\hline (Pseudo-)R2 & & 0.2588 & & 0.1957 & & 0.2667 \\
\hline
\end{tabular}

Note: Based on 9388 individuals aged 50 through 65 in 2004. 


\section{APPENDIX}

Table A1: Features of the old age and early retirement provisions

\begin{tabular}{|c|c|c|c|c|c|c|c|c|c|c|}
\hline Countries & Staturo & old-age & Eligibility rule & & Con & ution & & Benefit & & lin e $\max$ \\
\hline Austria & $\begin{array}{l}\text { Male } \\
\text { Female }\end{array}$ & 60 & 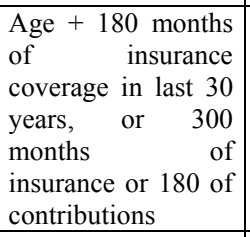 & $\begin{array}{l}61.5 \\
56.5\end{array}$ & $\begin{array}{l}\text { Employee } \\
\text { Employer }\end{array}$ & $\begin{array}{c}10,25 \% \text { of } \\
\text { earnings } \\
12,15 \% \text { of } \\
\text { payroll }\end{array}$ & $\begin{array}{l}\text { Regular } \\
\text { Early } \\
\text { retirement }\end{array}$ & $\begin{array}{l}\text { Benefit accrues at } 2 \% \text { of base } \mathrm{b}^{(5) \text { per }} \text { year of insurance } \\
\text { Reduction of } 3 \% \text { per year up to a max of } 10,5 \%\end{array}$ & $\begin{array}{l}\text { Min } \\
\text { Max }\end{array}$ & \\
\hline Belgium & Female & 65 & Age & 60 & $\begin{array}{l}\text { Employee } \\
\text { Employer }\end{array}$ & $\begin{array}{c}7,5 \% \text { of } \\
\text { earnings }\end{array}$ & $\begin{array}{l}\text { Regular } \\
\text { Early } \\
\text { retirement }\end{array}$ & $\begin{array}{l}60 \% \text { of average life-time earnings ( } 75 \% \text { for married couples) } \\
1310 \mathrm{CZK} \text { (base) }+1,5 \% \text { of } \mathrm{PAB}^{(6) \text { per }} \text { year of insurance }\end{array}$ & Max & $\begin{array}{l}, 253.11 \\
\text { euros a year } \\
\text { (single), } \\
11,562.55 \\
\text { euros a year } \\
\text { (married) } \\
38,678.50 \\
\text { euros a year }\end{array}$ \\
\hline Czech Republic & $\begin{array}{l}\text { Male } \\
\text { Female }\end{array}$ & $\begin{array}{c}62 \\
56-60^{*}\end{array}$ & Age & $\begin{array}{c}59 \\
53-57^{*}\end{array}$ & $\begin{array}{l}\text { Employee } \\
\text { Employer }\end{array}$ & $\begin{array}{l}6,5 \% \text { of } \\
\text { earnings } \\
21,5 \% \text { of } \\
\text { payroll }\end{array}$ & $\begin{array}{l}\text { Regular } \\
\text { Early } \\
\text { retirement }\end{array}$ & Reduction of $0.9 \%$ /every 90 -day period preceding the normal retirement age & $\begin{array}{l}\text { Min } \\
\text { Max }\end{array}$ & $2,080 \mathrm{CZK}$ \\
\hline Denmark & Male & 65 & $\begin{array}{l}\text { Age }+3 \text { to } 40 \text { years } \\
\text { of residence (public } \\
\text { pension); age } \quad+ \\
\text { years } \\
\text { contributions (ATP } \\
\text { and SP) }\end{array}$ & $60-66$ & Employee & None (2) & Regular & $\begin{array}{l}\text { Universal pension ( } 4,512 \mathrm{DKK} / \text { month) ATP and SP (Labor market supplementary } \\
\text { pension) depend on contribution's record } \\
\text { Partial retirement (work for } 12 \text { hours/week) : max } 86,892 \text { DKK per year }\end{array}$ & Max & \\
\hline France & Male & 60 & $\begin{array}{c}\text { Age }+1 / 4 \text { of } \\
\text { insurance coverage. }\end{array}$ & & Employee & $\begin{array}{l}6,55 \% \text { of } \\
\text { insurable } \\
\text { earnings }\end{array}$ & Regular & $25 \%$ to $50 \%$ of the average salary in the best $11-24$ years $^{(7)}$ & Min & $\begin{array}{c}6,307.62 \\
\text { euros a year }\end{array}$ \\
\hline
\end{tabular}




\begin{tabular}{|c|c|c|c|c|c|c|c|c|c|c|}
\hline & Female & 60 & & & Employer & $\begin{array}{c}8,2 \% \text { of } \\
\text { insurable } \\
\text { earnings }\end{array}$ & $\begin{array}{l}\text { Early } \\
\text { retirement }\end{array}$ & & $\operatorname{Max}$ & $\begin{array}{c}50 \% \text { of } \\
\text { max } \\
\text { earnings }\end{array}$ \\
\hline Germany & $\begin{array}{l}\text { Male } \\
\text { Female }\end{array}$ & 65 & $\begin{array}{l}\text { Age }+5 \text { years of } \\
\text { contributions }\end{array}$ & $59-63$ & $\begin{array}{l}\text { Employee } \\
\text { Employer }\end{array}$ & $\begin{array}{l}9,75 \% \text { of } \\
\text { earnings } \\
9,75 \% \text { of } \\
\text { payroll }\end{array}$ & $\begin{array}{l}\text { Regular } \\
\text { Early } \\
\text { retirement }\end{array}$ & $\begin{array}{l}\text { Individual earning points }{ }^{(8)} \times 1.0 \text { (pension factor) } \times \text { pension value (monthly benefit } \\
\text { amount for } 1 \text { year's average earnings, adjusted for changes in wages) } \\
\text { Reduction of the pension factor of } 0.003 / \text { calendar month before } 65 \text { years of age }\end{array}$ & $\begin{array}{l}\text { Min } \\
\text { Max }\end{array}$ & \\
\hline Greece & $\begin{array}{l}\text { Male } \\
\text { Female }\end{array}$ & 60 & $\begin{array}{l}\text { Age }+4,500 \text { days } \\
\text { of contributions; } \\
\text { Age } 62 / 57+10,000 \\
\text { days of } \\
\text { contributions; Age } \\
58+10,500 \text { days of } \\
\text { contributions; } \\
11,100 \text { days of } \\
\text { contributions }\end{array}$ & 55 & Employee & $\begin{array}{c}13,33- \\
14,73 \% \%^{(3)} \text { of } \\
\text { payroll } \\
\\
\\
\begin{array}{c}6,67- \\
8,87 \%{ }^{(3)} \text { of } \\
\text { earnings }\end{array}\end{array}$ & $\begin{array}{l}\text { Regular } \\
\text { Early } \\
\text { retirement }\end{array}$ & $\begin{array}{l}30-70 \% \text { of average earnings during the last } 5 \text { years (varying inversely with } \\
\text { earnings level) }+1 \% \text { of earnings/300 days of contribution between } 3300 \text { and } 7800 \\
+1,5-2,5 \% / 300 \text { days beyond } 7800 \\
\text { reduction of } 0,5 \% \text { for each month of early retirement }\end{array}$ & Min & $\begin{array}{l}360 \text { euros } \\
\text { per months }\end{array}$ \\
\hline Ireland & Male & 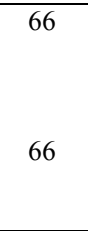 & $\begin{array}{l}\text { Age }+260 \text { weeks of } \\
\text { paid contributions } \\
\text { (started before age } \\
56 \text { and with year } \\
\text { average of } 48 \\
\text { weeks). }\end{array}$ & 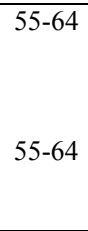 & Employee & $\begin{array}{l}0-6 \% \%^{(4)} \text { of } \\
\text { balance of } \\
\text { weekly } \\
\text { earnings } \\
8,5- \\
10,75 \%{ }^{(4)} \text { of } \\
\text { payroll }\end{array}$ & $\begin{array}{l}\text { Regular } \\
\text { Early } \\
\text { retirement }\end{array}$ & max 147.30/week; dependent supplement: $98.10-113.80$ (depending on age) & Max & $\begin{array}{l}147.30 \\
\text { euros per } \\
\text { week }\end{array}$ \\
\hline Italy & $\begin{array}{l}\text { Male } \\
\text { Female }\end{array}$ & $\begin{array}{c}57- \\
65(1) \\
\\
\\
\\
\\
\\
57- \\
60(1)\end{array}$ & Age + contributions & 57 & $\begin{array}{l}\text { Employee } \\
\text { Employer }\end{array}$ & $\begin{array}{c}8,89 \% \text { of } \\
\text { earnings } \\
\\
23,81 \% \text { of } \\
\text { payroll }\end{array}$ & $\begin{array}{l}\text { Regular } \\
\text { Early } \\
\text { retirement }\end{array}$ & $\begin{array}{l}\text { Newly insured (after } 1 \text { st January } 1996): 33 \% \text { of taxable base income } \times \text { age-dep. } \\
\text { coefficient }(4.72-6.136) ;<18 \text { years of contributions at } 1 \text { st January } 1996: 0.9-2 \% \text { of } \\
\text { salary x years of contribution (for period pre } 1 / 1 / 1996) \text { and as newly insured for } \\
\text { period after } 1 / 1 / 96 ;>18 \text { years of contribution: } 0.9-2 \% \text { of salary x years of } \\
\text { contribution. }\end{array}$ & $\begin{array}{l}\text { Min } \\
\\
\text { Max }\end{array}$ & 412,18 euro \\
\hline Netherlands & Male & 65 & $\begin{array}{l}\text { Age }+50 \text { years of } \\
\text { residence } \quad \text { and }\end{array}$ & & Employee & $\begin{array}{l}17,9 \% \text { of } \\
\text { earnings }\end{array}$ & Regular & $\begin{array}{l}\text { single: } 859.24 \text { euro; couple (both aged } 65 \text { or more): } 598.07 \text { each; single with child } \\
\text { (less the 18): } 1.077,54\end{array}$ & Min & \\
\hline
\end{tabular}




\begin{tabular}{|c|c|c|c|c|c|c|}
\hline Female & 65 & $\begin{array}{l}\text { contributions paid } \\
\text { (if income earners) } \\
\text { each year between } \\
\text { age } 15 \text { and } 64 .\end{array}$ & Employer & $\begin{array}{c}5,85 \% \text { of } \\
\text { payroll }\end{array}$ & $\begin{array}{l}\text { Early } \\
\text { retirement }\end{array}$ & Max \\
\hline
\end{tabular}




\begin{tabular}{|c|c|c|c|c|c|c|c|c|c|c|}
\hline Poland & $\begin{array}{l}\text { Male } \\
\text { Female }\end{array}$ & 60 & $\begin{array}{l}\text { Age }+25 \text { years of } \\
\text { insurance (men) } ; \\
\text { Age }+20 \text { years of } \\
\text { insurance (women). }\end{array}$ & & $\begin{array}{l}\text { Employee } \\
\text { Employer }\end{array}$ & $\begin{array}{c}9,76 \% \text { of } \\
\text { current gross } \\
\text { salary } \\
9,76 \% \text { of } \\
\text { payroll }\end{array}$ & $\begin{array}{l}\text { Regular } \\
\text { Early } \\
\text { retirement }\end{array}$ & $\begin{array}{l}24 \% \text { of average national salary; } 1,3 \% \text { of the workers earnings } \text { base }^{(9)} \mathrm{x} \\
\text { contribution years; } 0,7 \% \text { of workers earnings base } \mathrm{x} \text { credit years }\end{array}$ & $\begin{array}{l}\text { Min } \\
\text { Max }\end{array}$ & $\begin{array}{l}530.26 \\
\text { zlotys a } \\
\text { month }\end{array}$ \\
\hline Spain & Male & 65 & $\begin{array}{l}\text { Age }+15 \text { years of } \\
\text { contributions (at } \\
\text { least } 2 \text { in the last } 15 \\
\text { years). }\end{array}$ & 更 & Employer & $\begin{array}{c}23,6 \% \text { of } \\
\text { covered } \\
\text { earnings }\end{array}$ & 更 & $\begin{array}{l}50 \% \text { of benefit for first } 15 \text { years }+0,3 \% / \text { each year between the } 16-25 \text { years of } \\
\text { contributions }+2 \% / \text { each year after the } 26 \text { th up to a max of } 100 \% \text {. } \\
\text { Reduction between } 6-8 \% \text { (depending on years of contribution) for each year less } \\
\text { than age } 65\end{array}$ & 更 & $\begin{array}{l}385.50 \\
\text { euros per } \\
\text { month } \\
\text { (single), } \\
453.98 \\
\text { (with } \\
\text { dependent } \\
\text { spouse) } \\
\text { maximum } \\
\text { public } \\
\text { pension } \\
\text { benefit }\end{array}$ \\
\hline Sweden & $\begin{array}{l}\text { Male } \\
\text { Female }\end{array}$ & 65 & $\begin{array}{l}\text { Age }+3 \text { years of } \\
\text { coverage (earning- } \\
\text { related); age }+3 \\
\text { years of residence } \\
\text { (public). }\end{array}$ & $\begin{array}{r}61-64 \\
61-64\end{array}$ & Employer & $\begin{array}{c}7 \% \text { of } \\
\text { assessable } \\
\text { income } \\
\begin{array}{c}10,21 \% \text { of } \\
\text { payroll }\end{array}\end{array}$ & $\begin{array}{l}\text { Regular } \\
\text { Early } \\
\text { retirement }\end{array}$ & $\begin{array}{l}\text { Total accrued divided by (annual index based on average wages reported to } \\
\text { pension system }+ \text { annuity factor depending on life expectancy and expected } \\
\text { increase of average wage) }\end{array}$ & Max & $\begin{array}{l}7.5 \text { times } \\
\text { base } \\
\text { amount }\end{array}$ \\
\hline Switzerland & $\begin{array}{l}\text { Male } \\
\text { Female }\end{array}$ & 65 & $\begin{array}{l}\text { Age }+ \text { contributions } \\
\text { from age } 21 .\end{array}$ & & $\begin{array}{l}\text { Employee } \\
\text { Employer }\end{array}$ & $\begin{array}{l}4,2 \% \text { of } \\
\text { income }\end{array}$ & $\begin{array}{l}\text { Regular } \\
\text { Early } \\
\text { retirement }\end{array}$ & $\begin{array}{l}\text { Base pension: average annual income }<37.080 \text { francs: } 9,146+\text { (annual income } x \\
13 / 600) \text {; average annual income }>37.080 \text { francs: } 12.854+(\text { annual income } x 8 / 600) \text {. } \\
\text { Mandatory occupational pension: } 7.2 \% \text { of accumulated funds }\end{array}$ & $\begin{array}{l}\text { Min } \\
\text { Max }\end{array}$ & $\begin{array}{l}1,030 \\
\text { francs a } \\
\text { month } \\
\\
2,060 \\
\text { francs a } \\
\text { month } \\
\end{array}$ \\
\hline
\end{tabular}


Notes to Table A1

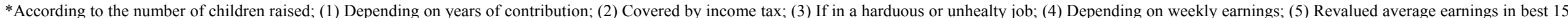

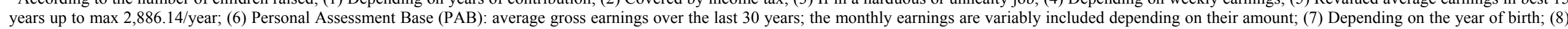

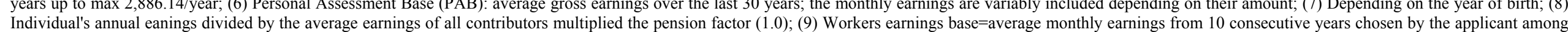
the 19 years prior the year of the pension application 
Table A2: Features of the unemployment provisions

\begin{tabular}{|c|c|c|c|c|c|c|}
\hline Countries & Qualifying conditions & & tions & Benefit & & in e $\max$ \\
\hline Austria & $\begin{array}{l}28 \text { weeks of contributions in the last } \\
12 \text { months (52 weeks in the last } 24 \\
\text { months if first claim), registered at } \\
\text { the employment office, capable of } \\
\text { and willing to work. }\end{array}$ & $\begin{array}{l}\text { Employer } \\
\text { Employee } \\
\text { Government }\end{array}$ & $\begin{array}{l}3 \% \text { of earnings } \\
3 \% \text { of payroll } \\
\text { any deficit }\end{array}$ & $\begin{array}{l}55 \% \text { of net earnings. Payable for } \\
\text { up to } 20 \text { weeks (extendable to } 30 \\
\text { to } 78 \text { weeks depending on certain } \\
\text { conditions of age and } \\
\text { contributions) }\end{array}$ & Min & $\begin{array}{l}4.08 \text { euros per day } \\
33.82 \text { euros per day }\end{array}$ \\
\hline Belgium & $\begin{array}{l}312 \text { days of insured employment or } \\
\text { deemed employment in the last } 18 \\
\text { months }(<36 \text { years old), } 468 \text { days in } \\
\text { the last } 27 \text { months ( } 36 \text { to } 50), 624 \\
\text { days in the last } 36 \text { months (over } 50 \text { ), } \\
\text { registration at the employment } \\
\text { office, capable of and willing to } \\
\text { work. }\end{array}$ & $\begin{array}{l}\text { Employer } \\
\text { Employee } \\
\text { Government }\end{array}$ & $\begin{array}{l}0,87 \% \text { of earnings } \\
1,46 \% \text { of earnings } \\
\text { any deficit }\end{array}$ & $\begin{array}{l}60 \% \text { for all period (household } \\
\text { head), } 60 \% 1 \text { st year and } 44 \% \\
\text { thereafter (single person living } \\
\text { alone), } 55 \% 1 \text { st year and } 35 \% \\
\text { thereafer (single person living } \\
\text { with other people) }\end{array}$ & Min & 58.83 euros per day \\
\hline Czech Republic & $\begin{array}{l}\text { Registered with the Labor Offices as } \\
\text { looking for work, employment for at } \\
\text { least } 12 \text { months in the past } 3 \text { years. }\end{array}$ & $\begin{array}{l}\text { Employer } \\
\text { Employee } \\
\text { Government }\end{array}$ & $\begin{array}{l}0,4 \% \text { of earnings } \\
3,2 \% \text { of payroll } \\
\text { any deficit }\end{array}$ & $\begin{array}{l}50 \% \text { of eanings during the first } 3 \\
\text { months, } 40 \% \text { the next } 3 \text { months; } \\
60 \% \text { in case of retraining }\end{array}$ & $\begin{array}{l}\text { Min } \\
\text { Max }\end{array}$ & 10,250 CZK per month \\
\hline
\end{tabular}




\begin{tabular}{|c|c|c|c|c|c|c|}
\hline \multirow[t]{3}{*}{ Denmark } & $\begin{array}{l}\text { Membership in a unemployment } \\
\text { fund during the last } 12 \text { months and } \\
52 \text { weeks of employment in the last } \\
3 \text { years, capable of and willing to } \\
\text { work. }\end{array}$ & Employer & $\begin{array}{l}\text { Membership } \\
\text { contribution to the } \\
\text { unemployment fund } \\
+8 \% \text { of the gross } \\
\text { income toward the } \\
\text { Labor Market fund. }\end{array}$ & $\begin{array}{l}90 \% \text { of the average earnings of } \\
\text { the preceding } 12 \text { weeks. Benefit } \\
\text { payable from the } 1 \text { st day up to } 1 \\
\text { year (job seeking period), this } \\
\text { period may be followed by } \\
\text { another } 3 \text { years period }\end{array}$ & Min & \\
\hline & & Employee & $\begin{array}{l}3 \% \text { value-added tax } \\
\text { base of the enterprise }\end{array}$ & & Max & $\begin{array}{c}604 \text { DKK a day } \\
\text { (157,040 DKK a year) }\end{array}$ \\
\hline & & Government & $\begin{array}{c}\text { any cost above } \\
\text { employer/employee } \\
\text { contributions }\end{array}$ & & & \\
\hline France & $\begin{array}{l}<60 \text { years of age (between } 60 \text { and } \\
65 \text { if without enough required } \\
\text { quarter of coverage for old-age } \\
\text { pension), } 4 \text { months of work during } \\
\text { the last } 18 \text { months, resident in } \\
\text { France, registered at the } \\
\text { employment office, capable of and } \\
\text { willing to work. }\end{array}$ & $\begin{array}{l}\text { Employer } \\
\text { Employee } \\
\text { Government }\end{array}$ & $\begin{array}{c}\begin{array}{c}2 \% \text { of monthly } \\
\text { earnings }\end{array} \\
3,60 \% \text { of payroll } \\
\text { Total cost of } \\
\text { solidarity program }\end{array}$ & $\begin{array}{l}57,4 \% \text { and } 75 \% \text { of the daily } \\
\text { reference wage. The duration of } \\
\text { benefit varies according to age ( } 4 \\
\text { to } 30 \text { months if }<50,5 \text { to } 60 \\
\text { months if }>50 \text { ) }\end{array}$ & Max & \\
\hline Germany & $\begin{array}{l}\text { Personally registered at employment } \\
\text { office, capable of and willing to } \\
\text { work, } 360 \text { days of insured } \\
\text { employment in the last } 3 \text { years. }\end{array}$ & $\begin{array}{l}\text { Employer } \\
\text { Employee }\end{array}$ & $\begin{array}{c}3,25 \% \text { of covered } \\
\text { earnings } \\
3,25 \% \text { of covered } \\
\text { earnings }\end{array}$ & $\begin{array}{l}67 \% \text { of net earnings for } \\
\text { unemployed with children ( } 60 \% \text { if } \\
\text { no children). Benefit payable for } \\
180 \text { to } 960 \text { calendar days } \\
\text { according to the lenght of insured } \\
\text { employment and age. }\end{array}$ & $\begin{array}{l}\text { Min } \\
\text { Max }\end{array}$ & \\
\hline & & Government & any deficit & & & \\
\hline
\end{tabular}




\begin{tabular}{|c|c|c|c|c|c|c|}
\hline Greece & $\begin{array}{l}125 \text { days of contributions in the last } \\
14 \text { months (or } 200 \text { days in the last } 2 \\
\text { years), capable of and willing to } \\
\text { work, registered at the employment } \\
\text { office. }\end{array}$ & $\begin{array}{l}\text { Employer } \\
\text { Employee } \\
\text { Government }\end{array}$ & $\begin{array}{l}2,67 \% \text { of payroll } \\
\text { none }\end{array}$ & $\begin{array}{l}40 \% \text { of wages or } 50 \% \text { of salary. } \\
\text { Benefit payable after a } 6 \text {-day } \\
\text { waiting period for } 125 \text { days of } \\
\text { employment for up to } 5 \text { months, } \\
150 \text { days up to } 6 \text { months, } 250 \\
\text { days up to } 8 \text { months, } 220 \text { days up } \\
\text { to } 10 \text { months, } 250 \text { days if }>49 \text {, } \\
210 \text { days up to } 12 \text { months. }\end{array}$ & $\operatorname{Max}$ & 9,94 euros per day \\
\hline Ireland & $\begin{array}{l}\text { Age } 16 \text { to } 65 \text {, unemployed for at } \\
\text { least } 3 \text { days in } 6 \text { consecutive days, } \\
39 \text { week of paid contributions, } \\
\text { capabel of and willing to work, } \\
\text { registered at Social Welfare Local } \\
\text { Office. }\end{array}$ & $\begin{array}{l}\text { Employer } \\
\text { Employee } \\
\text { Government }\end{array}$ & $\begin{array}{l}\text { See old-age pension } \\
\text { See old-age pension } \\
\text { Any deficit }\end{array}$ & $\begin{array}{l}118,80 / \text { week payable for up to } 15 \\
\text { months ( } 156 \text { days if }<18 \text { and } 156 \\
\text { weeks if }>=65 \text { ) }\end{array}$ & $\operatorname{Max}$ & 118.80 euros a week \\
\hline Itally & $\begin{array}{l}2 \text { years coverage with } 52 \text { weeks of } \\
\text { contributions in the last } 2 \text { years. } \\
\text { Mobility allowance: industrial } \\
\text { workers, } 1 \text { year of insurance, } 6 \\
\text { months of employment, registered at } \\
\text { the employment office, capable of } \\
\text { and willing to work }\end{array}$ & $\begin{array}{l}\text { Employee } \\
\text { Government }\end{array}$ & $\begin{array}{c}1,61 \% \text { to } 1,91 \% \text { of } \\
\text { payroll } \\
\text { Administrative costs }\end{array}$ & $\begin{array}{l}40 \% \text { of salary payable for up to } \\
180 \text { days ( } 270 \text { for workers }>50 \text { ) } \\
\text { (private sector workers). Mobility } \\
\text { allowance: for first } 12 \text { months } \\
100 \% \text { of benefit, thereafter } 80 \% \text {, } \\
\text { payable up to } 48 \text { months. }\end{array}$ & Min & \\
\hline The Netherlands & $\begin{array}{l}26 \text { weeks of employment in the last } \\
39 \text { weeks (basic benefit), } 52 \text { days in } \\
4 \text { years of the } 5 \text { preceding years } \\
\text { (salary related benefit) }\end{array}$ & $\begin{array}{l}\text { Employer } \\
\text { Employee } \\
\text { Government }\end{array}$ & $\begin{array}{l}\text { None } \\
\text { None } \\
\text { Total cost }\end{array}$ & $\begin{array}{l}70 \% \text { of the minimum wage (basic } \\
\text { benefit), } 70 \% \text { of the last salary } \\
\text { (salary related benefit) }\end{array}$ & $\begin{array}{l}\text { Min } \\
\text { Max }\end{array}$ & \\
\hline
\end{tabular}




\begin{tabular}{|c|c|c|c|c|c|c|}
\hline Poland & $\begin{array}{l}\text { Registered with the employment } \\
\text { bureau, } 180 \text { days of employment in } \\
\text { the past year, have complete } \\
\text { education, newly released from the } \\
\text { military service, completed } \\
\text { maternity leave, or been released } \\
\text { from prison. }\end{array}$ & $\begin{array}{l}\text { Employer } \\
\text { Employee } \\
\text { Government }\end{array}$ & $\begin{array}{l}\text { None } \\
3 \% \text { of payroll } \\
\text { any deficit }\end{array}$ & $\begin{array}{l}\text { Base amount for workers between } \\
5 \text { and } 20 \text { years of employment, } \\
80 \% \text { of base amount if }<5 \text { years, } \\
120 \% \text { if }>20 \text { years. Benefit } \\
\text { payable for } 6 \text { to } 18 \text { months }\end{array}$ & Max & \\
\hline Spain & $\begin{array}{l}12 \text { months of contributions during } \\
\text { the last } 6 \text { years, registration at the } \\
\text { employment office. }\end{array}$ & $\begin{array}{l}\text { Employer } \\
\text { Employee } \\
\text { Government }\end{array}$ & 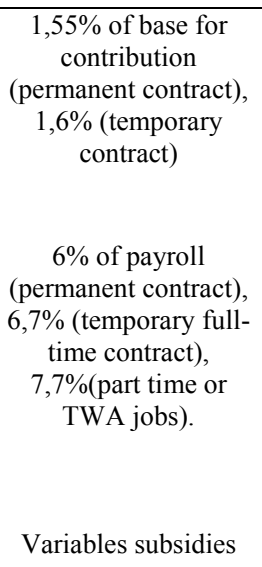 & $\begin{array}{l}70 \% \text { of average earnings during } \\
\text { the last } 6 \text { months for up to } 180 \\
\text { days, } 60 \% \text { after } 180 \text { days. }\end{array}$ & $\begin{array}{l}\text { Min } \\
\text { Max }\end{array}$ & $\begin{array}{c}75 \% \text { of the minimum } \\
\text { wage, } 100 \% \text { of the } \\
\text { minimum } \\
\text { interprofessional salary } \\
170 \% \text { of the minimum } \\
\text { interprofessional salary }\end{array}$ \\
\hline Sweden & $\begin{array}{l}\text { Unemployed, registered as } \\
\text { jobseekers at the public employment } \\
\text { service, able and willing to accept a } \\
\text { suitable job for at least } 3 \text { hours/day } \\
\text { (17 hours a week). }\end{array}$ & $\begin{array}{l}\text { Employer } \\
\text { Employee } \\
\text { Government }\end{array}$ & $\begin{array}{c}\text { None } \\
\\
\text { None } \\
\begin{array}{c}93 \% \text { of cost through } \\
\text { appropriation }\end{array}\end{array}$ & $\begin{array}{l}270 \text { kronor per day } \text { (basic } \\
\text { unemployment benefit). Payable } \\
\text { up to } 300 \text { days per unemployment } \\
\text { spell }\end{array}$ & Max & \\
\hline
\end{tabular}




\begin{tabular}{|c|c|c|c|c|c|}
\hline Switzerland & $\begin{array}{l}\text { Live in Switzerland, } 6 \text { months of } \\
\text { employment in the last } 2 \text { years, } \\
\text { willing and able to work, report } \\
\text { once a month to unemployment } \\
\text { office. }\end{array}$ & $\begin{array}{l}\text { Employee } \\
\text { Government }\end{array}$ & $\begin{array}{l}1,5 \% \text { of payroll } \\
\text { cover deficit }\end{array}$ & $\begin{array}{l}80 \% \text { of the last earnings (if } \\
\text { dependents, low income, } \\
\text { disabled), } 70 \% \text { for all other. } \\
\text { Benefit payable after 5-days } \\
\text { waiting period }\end{array}$ & $\begin{array}{l}\text { Min } \\
\text { Max }\end{array}$ \\
\hline
\end{tabular}

Notes to Table A2:

In all countries unemployment is not due to voluntary departure without good reason, misconduct, work stoppage or refusal of suitable job. 
Table A3: Disability insurance schemes considered

\begin{tabular}{|c|c|}
\hline Austria (AT) & Staatliche Invaliditätspension \\
\hline Belgium (BE) & $\begin{array}{l}\text { Assurance invalidité légale/Wettelijke uitkering wegens arbeidsongeval of beroeps- } \\
\text { ziekte; Pension de maladie, d'invalidité, maladie professionnelle/Wettelijke uitkering } \\
\text { wegens ziekte of invaliditeit of tegemoetkoming aan personen met een handicap }\end{array}$ \\
\hline Switzerland $(\mathrm{CH})$ & Invalidenrente aus IV, assurance invalidité légale $(\mathrm{AI})$ and Rendità invalidità $(\mathrm{AI})$ \\
\hline Germany (DE) & Erwerbsminderungsrente and Beamtenpension wegen Dienstunfähigkeit \\
\hline Denmark (DK) & Offentlig sygedagpenge and offentlig førtidspension \\
\hline Spain (ES) & Pensión pública contributiva y no contributiva de invalidez/incapacidad \\
\hline France $(\mathrm{FR})$ & Prestation publique d'invalidité (AAH, APA) \\
\hline Greece (GR) & $\Sigma v ́ v \tau \alpha \xi \eta \alpha v \alpha \pi \eta \rho i ́ \alpha \varsigma$ \\
\hline Italy (IT) & $\begin{array}{l}\text { Assicurazione pubblica di disabilità (anche assegno di accompagnamento)" and } \\
\text { pnsione pubblica di invalidità o di inabilità }\end{array}$ \\
\hline Netherlands (NL) & $\begin{array}{l}\text { WAO, Waz of invaliditeitspensioen and Algemene bijstandswet (Abw), } \\
\text { IOAW/IOAZ, aanvullende bijstandsuitkering, Toeslagenwet (TW) }\end{array}$ \\
\hline Sweden (SE) & Förtidspension (sjukersättning), yrkesskadepension, and sjukbidrag \\
\hline England (UK) & Incapacity benefits (previously invalidity benefits) \\
\hline United States (US) & SSDI and SSI disability pension \\
\hline
\end{tabular}

Disability insurance is defined as all branches of publicly financed insurances against the loss of the ability to perform gainful employment. The Table lists the institutions in each country by their proper name. 
Table A4: Features of the disability provisions

\begin{tabular}{|c|c|c|c|c|c|c|}
\hline Countries & \multicolumn{2}{|c|}{ Qualifying conditions } & \multicolumn{2}{|l|}{ Benefit } & \multicolumn{2}{|c|}{ Min max } \\
\hline \multirow[t]{3}{*}{ Austria } & Loss of earning capacity & $50 \%$ & Disability pension & $\begin{array}{l}\text { Like old age pension. Max is } 60 \% \text { of } \\
\text { assessment base }\end{array}$ & Min & \\
\hline & Contribution & $\begin{array}{l}60 \text { months in the last } 10 \text { years } \\
+300 \text { months of insurance; or } \\
180 \text { months in total }\end{array}$ & Others related & $\begin{array}{l}\text { Care benefit: monthly benefit between } \\
145,40 \text { to } 1,531.50 \text { euro }\end{array}$ & $\operatorname{Max}$ & $\begin{array}{l}60 \% \text { of assessment } \\
\text { base }\end{array}$ \\
\hline & Others & & & & & \\
\hline \multirow[t]{3}{*}{ Belgium } & Loss of earning capacity & $2 / 3$ & Disability pension & $\begin{array}{l}65 \% \text { of lost wages with a ceiling (with } \\
\text { dependents), } 40 \% \text { (with no dependents), } \\
45 \% \text { (if no dependents but living with } \\
\text { no income people) }\end{array}$ & Min & $\begin{array}{l}25.11 \text { euros a day } \\
\text { (no dependents), } \\
28.01 \text { a day (if } \\
\text { living alone), } 35.08 \\
\text { (with dependents) }\end{array}$ \\
\hline & Contribution & $\begin{array}{l}6 \text { months + insurance cover } \\
\text { during last quarter }\end{array}$ & Others related & the 1st year under sickness benefit & Max & $\begin{array}{l}36.69 \text { euros a day } \\
\text { (no dependents), } \\
59.54 \text { a days (with } \\
\text { dependents) }\end{array}$ \\
\hline & Others & & & & & \\
\hline \multirow[t]{3}{*}{ Czech Republic } & Loss of earning capacity & $\begin{array}{l}\text { 66\% (totale disability); } 33 \% \\
\text { (partial disability) }\end{array}$ & Disability pension & $\begin{array}{l}\text { Full pension: } 1,310 \mathrm{CZK}+1,5 \% / \text { year } \\
\text { of insurance of the personale } \\
\text { assessment base }(\min 2,080 \mathrm{CZK}) \text {. } \\
\text { Partial disability: } 1,310 \mathrm{CZK}+ \\
0,75 \% \text { /year of insurance of the personal } \\
\text { assessment base (min } 1,695 \mathrm{CZK} \text { ) }\end{array}$ & Min & $\begin{array}{l}\text { 2,080 CZK (total } \\
\text { disability), } 1,695 \\
\text { CZK (partial } \\
\text { disability) }\end{array}$ \\
\hline & Contribution & $\begin{array}{l}5 \text { years (up to } 4 \text { if }<28 \text { years } \\
\text { of age) of insurance in the last } \\
10 \text { years }\end{array}$ & Others related & & Max & no $\max$ \\
\hline & Others & & & & & \\
\hline
\end{tabular}




\begin{tabular}{|c|c|c|c|c|c|c|}
\hline \multirow[t]{3}{*}{ Denmark } & Loss of earning capacity & $\begin{array}{l}50 \% \text { (universal disability } \\
\text { pension); } 100 \% \text { (partial } \\
\text { unemployment supplement); } \\
100 \% \text { (permanent total } \\
\text { disability pension); } 2 / 3 \\
\text { (permanent severe disability } \\
\text { pension); } 50 \% \text { (partial } \\
\text { disability pension) }\end{array}$ & Disability pension & $\begin{array}{l}\text { 4,377 DKK (monthly), supplement } \\
\text { 4,406 DKK (monthly). }\end{array}$ & Min & \\
\hline & Contribution & & Others related & $\begin{array}{l}\text { Disablement supplement }(2,129 \\
\text { DKK/month); unemployment } \\
\text { supplement (2,939 DKK/month); early } \\
\text { retirement supplement for partial } \\
\text { disability (1,113 DKK/months); } \\
\text { disability allowance ( } 2,142 \\
\text { DKK/months); outside assistance } \\
\text { allowance (2,224 DKK/month) }\end{array}$ & Max & $\begin{array}{l}4,377 \text { DKK a } \\
\text { month (universal } \\
\text { basic)+ 4,406 DKK } \\
\text { a month (disability } \\
\text { supplement) + } \\
2,129 \text { DKK a } \\
\text { month (disablement } \\
\text { supplement) + } \\
2,939 \text { DKK a } \\
\text { month } \\
\text { (unemployment } \\
\text { supplement) }\end{array}$ \\
\hline & Others & \multicolumn{5}{|c|}{3 years of residence since 15 years of age (universal disability pension); 4 to 5 years of residence to have full pension } \\
\hline \multirow{2}{*}{ France } & Contribution & 12 months & Others related & $\begin{array}{l}\text { Constant attendace allowance } \\
\text { supplement }(916,32 / \text { months })\end{array}$ & Max & $\begin{array}{l}1,176 \text { euros a } \\
\text { month }\end{array}$ \\
\hline & Others & \multicolumn{3}{|c|}{800 hours of employment in the last 12 months (200 hours in the last 3 months) } & & \\
\hline
\end{tabular}




\begin{tabular}{|c|c|c|c|c|c|c|}
\hline \multirow[t]{3}{*}{ Germany } & Loss of earning capacity & $\begin{array}{l}\text { Full reduction ( }<3 \text { hours of } \\
\text { work per day) or partial } \\
\text { reduction }(<6 \text { hours per day) }\end{array}$ & Disability pension & $\begin{array}{l}\text { Like old-age pension. Full pension } \\
\text { (pension factor } 1.0 \text { ); partial disability } \\
\text { (pension factor } 0.5 \text { ) }\end{array}$ & Min & \\
\hline & Contribution & $\begin{array}{l}5 \text { years of contribution }+36 \\
\text { months of compulsory } \\
\text { contributions out of the last } 5 \\
\text { years }\end{array}$ & Others related & & Max & \\
\hline & Others & & & & & \\
\hline \multirow[t]{3}{*}{ Greece } & Loss of earning capacity & $\begin{array}{l}80 \% \text { (full disability pension); } \\
50 \% \text { (partial disability } \\
\text { pension) }\end{array}$ & Disability pension & $\begin{array}{l}\text { Like old - age pension. Loss of } 80 \% \text { of } \\
\text { earning capacity ( } 100 \% \text { of full old-age } \\
\text { pension), loss of } 67 \% \text { to } 79 \% \text { ( } 75 \% \text { of } \\
\text { full old-age pension); loss of } 50 \% \text { to } \\
66 \%(50 \% \text { of the full old-age pension). } \\
\text { Minimum } 360 / \text { month }\end{array}$ & Min & $\begin{array}{l}360 \text { euros per } \\
\text { month }\end{array}$ \\
\hline & Contribution & $\begin{array}{l}4,500 \text { days; } 1,500 \text { days } \\
\text { (incuding } 600 \text { days in the last } \\
5 \text { years); for }<21 \text { years of age } \\
\text { ( } 300 \text { days in the } 5 \text { last years) }\end{array}$ & Others related & & Max & \\
\hline & Others & & & & & \\
\hline \multirow[t]{3}{*}{ Ireland } & Loss of earning capacity & $\begin{array}{l}\text { Permanent incapacity for } \\
\text { work }\end{array}$ & Disability pension & $\begin{array}{l}\text { Disability pension: } 123,30 / \text { week, } \\
147,30 \text { if }>65 \text { years of age; dependent } \\
\text { supplement: } 88 / \text { week for adult } \\
\text { dependent }+19,30 / \text { week for each } \\
\text { dependent child under age } 18 ; \text { disability } \\
\text { allowance: up to } 118,80 / \text { week }+78,20 \\
\text { (adult dependent) }+16,80 \text { (child } \\
\text { dependent) }\end{array}$ & Min & \\
\hline & Contribution & 260 weeks ( 48 in the last year) & Others related & $\begin{array}{l}\text { Blind person's pension: up to } \\
118,80 / \text { week }+78,80 \text { for dependent } \\
\text { adult; special allowance: } 7,70 / \text { week } \\
\text { (single pensioner }>=66 \text { years of age } \\
\text { living alone) or } 8,40 \text { (if }>=80 \text { years of } \\
\text { age) }\end{array}$ & Max & \\
\hline & Others & \multicolumn{3}{|c|}{1 year of ordinary sickness benefit ( $<1$ year if severe disability) } & & \\
\hline
\end{tabular}




\begin{tabular}{|c|c|c|c|c|c|c|}
\hline \multirow[t]{3}{*}{ Italy } & Loss of earning capacity & $\begin{array}{l}\text { total and permanent inability } \\
\text { to work (disability pension); } \\
2 / 3 \text { (disability allowance) }\end{array}$ & Disability pension & $\begin{array}{l}\text { Disability pension: same as for the old- } \\
\text { age pension + increment based on the } \\
\text { anticipated n. of years between date of } \\
\text { onset disability and normal age pension. } \\
\text { Disability allowance: min } 392,69 / \text { month }\end{array}$ & Min & $\begin{array}{l}392.69 \text { euros } \\
\text { (526.46 euros per } \\
\text { month if } 60 \text { years } \\
\text { old and low } \\
\text { income). } 6,714 \\
\text { euros a year } \\
\text { (single), } 11,271.39 \\
\text { euros a year } \\
\text { (couple) }\end{array}$ \\
\hline & Contribution & $\begin{array}{l}5 \text { years (including } 3 \text { years in } \\
\text { the last } 5 \text { years) (disability } \\
\text { pension and allowance) }\end{array}$ & Others related & $\begin{array}{l}\text { Constant attendance supplement: } \\
369,27 / \text { month }\end{array}$ & Max & \\
\hline & Others & \multicolumn{5}{|c|}{$\begin{array}{l}\text { absence of other forms on income (disability pension); reduction of } 25 \% \text { if income }=4 \times \text { minimum income and of } 50 \% \text { if income }=5 \times \\
\text { minimum income (disability allowance) }\end{array}$} \\
\hline \multirow[t]{3}{*}{ The Netherlands } & Loss of earning capacity & $\begin{array}{l}80 \% \text { (full pension); } 15-80 \% \\
\text { (partial pension); } 25-80 \% \\
\text { (unemployed, disabled since } \\
\text { childhood, students) }\end{array}$ & Disability pension & $\begin{array}{l}\text { Disability pension (employee): up to } \\
70 \% \text { of earnings ( } 80 \% \text { of disability), } \\
14-50,75 \% \text { ( } 15-80 \% \text { of disability). } \\
\text { Disability pension (disabled since } \\
\text { childhood and students): } 70 \% \text { of the } \\
\text { minimum wage ( } 80 \% \text { of disability), } \\
14 \% \text { to } 50,75 \% \text { ( } 25-80 \% \text { disability) }\end{array}$ & Min & \\
\hline & Contribution & & Others related & $\begin{array}{l}\text { Constant attendance supplement (for } \\
\text { all): } 30 \% \text { of the full pension }\end{array}$ & Max & 159.99 a day \\
\hline & Others & & & & & \\
\hline \multirow[t]{3}{*}{ Poland } & Loss of earning capacity & total or partial disability & Disability pension & $\begin{array}{l}\text { Total disability: } 24 \% \text { of the average } \\
\text { national salary } 1,3 \% \text { of the worker's } \\
\text { earning base }{ }^{(1)} \mathrm{x} \text { number of contribution } \\
\text { years, } 0,7 \% \text { of the worker's earning base } \\
\mathrm{x} \text { number of credit years }{ }^{(2)} \text {. Partial } \\
\text { disability: } 75 \% \text { of amount of total } \\
\text { disability pension }\end{array}$ & Min & $\begin{array}{l}530.26 \text { zlotys a } \\
\text { month (total } \\
\text { disability), } 407.88 \\
\text { zlotys a month } \\
\text { (partial disability) }\end{array}$ \\
\hline & Contribution & $\begin{array}{l}5 \text { years in the last } 10 \text { years ( } 1 \\
\text { to } 4 \text { if }<30 \text { years of age) }\end{array}$ & Others related & & \multirow[t]{2}{*}{ Max } & \\
\hline & Others & \multicolumn{3}{|c|}{ disability during employment; disability within 18 months of cessation of work } & & \\
\hline
\end{tabular}




\begin{tabular}{|c|c|c|c|c|c|c|}
\hline \multirow[t]{3}{*}{ Spain } & Loss of earning capacity & $\begin{array}{l}\text { Loss of normal earning } \\
\text { capacity }\end{array}$ & Disability pension & $\begin{array}{l}\text { Pemanent total disability: all work } \\
\text { ( } 100 \% \text { of the benefit base up to max } \\
\text { earnings for contribution purposes); } \\
\text { occupational ( } 55 \% \text { of the benefit base }+ \\
20 \% \text { if }>=55 \text { years of age). Permanent } \\
\text { partial disability: } 24 x \text { the monthly } \\
\text { benefit base for temporary dis. }\end{array}$ & Min & $\begin{array}{l}385.50 \text { a month (if } \\
65 \text { years old), } \\
453.98 \text { euros a } \\
\text { month (with } \\
\text { dependent spouse) }\end{array}$ \\
\hline & Contribution & $\begin{array}{l}1 / 2 \text { of the time between } 16 \\
\text { and the onset of disability } \\
(<26 \text { years of age); } 1 / 4 \text { of the } \\
\text { time between } 20 \text { and the onset } \\
\text { of disability ( }>26 \text { years of } \\
\text { age); at least } 5 \text { years, } 1 / 5 \text { of } \\
\text { contribution in the last } 10 \\
\text { years (in general) }\end{array}$ & Others related & $\begin{array}{l}\text { Constant attendance supplement: } 50 \% \\
\text { of the value of the pension }\end{array}$ & Max & \\
\hline & Others & & & & & \\
\hline \multirow[t]{3}{*}{ Sweden } & Loss of earning capacity & $\begin{array}{l}3 / 4,1 / 2 \text { and } 1 / 4 \text { (universal } \\
\text { disability pension and } \\
\text { earnings related disability } \\
\text { pension) }\end{array}$ & Disability pension & $\begin{array}{l}\text { Universal disability pension: } 90 \% \text { of } \\
\text { reduced current base amount } \mathrm{x} \text { the } \\
\text { accrued number of } 40 \mathrm{~s} \text { and } 30 \mathrm{~s} \text { (single } \\
\text { pensioner); } 72,5 \% \text { (married pensioner). } \\
\text { Earnings-related disability pension: } \\
\text { computed as old-age pension. Partial } \\
\text { disability: } 3 / 4,1 / 4 \text { or } 1 / 2\end{array}$ & Min & \\
\hline & Contribution & & Others related & $\begin{array}{l}\text { Constant attendance supplement: up to } \\
65 \% \text { of base amount }\end{array}$ & Max & \\
\hline & Others & & & & & \\
\hline
\end{tabular}




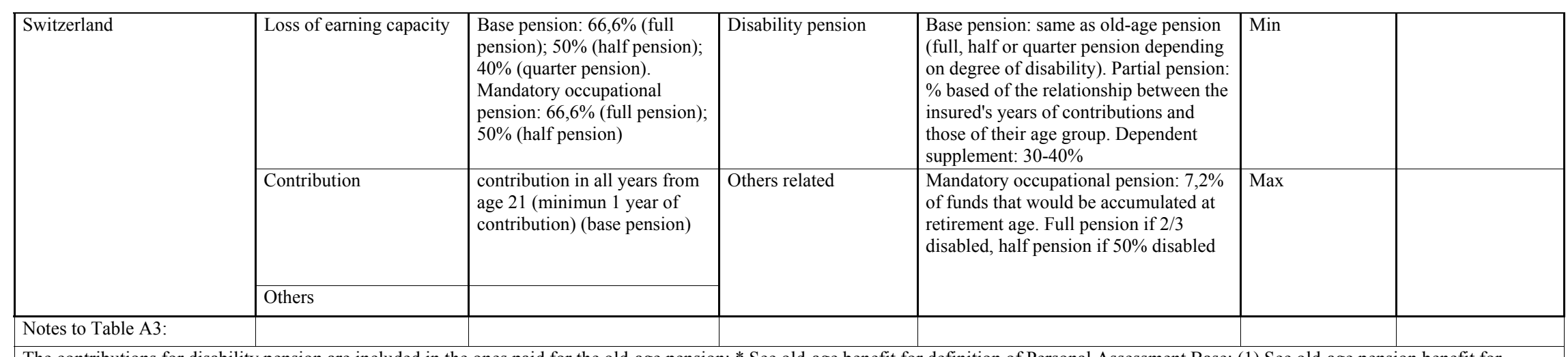

The contributions for disability pension are included in the ones paid for the old-age pension; * See old-age benefit for definition of Personal Assessment Base; (1) See old-age pension benefit for definition of Worker's earning base; (2) Credit years: for example years spent rearing children. 